\title{
MERCADERES Y HOMBRES DE NEGOCIO: EL PODER DEL DINERO EN EL MUNDO URBANO RIOJANO DE FINES DE LA EDAD MEDIA E INICIOS DE LA EDAD MODERNA*
}

\section{FCO. JAVIER GOICOLEA JULIÁN}

Universidad de La Rioja

RESUMEN: Los mercaderes conformaron a fines del Medievo e inicios de la Edad Moderna uno de los grupos sociales dotados de mayor dinamismo y poder en las ciudades y villas riojanas. A lo largo del presente estudio pretendemos dar a conocer algunas de las características de estos miembros de la sociedad urbana riojana. Para ello se analizarán sus actividades económicas vinculadas al comercio y a otros negocios igualmente rentables. Como podremos comprobar, estas actividades les permitieron ir conformando unas haciendas y patrimonios que les situaron como los personajes más ricos de las localidades donde vivían, al mismo tiempo que les posibilitaron llevar unos modos de vida acordes con el elitista ideal caballeresco propio de los sectores aristocráticos de la sociedad de ese momento.

Palabras Clave: Mercaderes. Ciudades. La Rioja. Siglos XV-XVI. Economía. Patrimonio. Modos de vida.

ABSTRACT: At the end of the Middle Ages and beginning of the Modern Era, merchants made up one of the most dynamic and powerful social groups in La Rioja's cities and towns. Throughout this research, we intend to show some features on these members of La Rioja's urban society. With this in mind, we will analyse the economic activities linked to trade and to other equally profitable businesses. As we will see, these activities allowed them to create the wealth that made them the richest people where they live in, while, at the same time, enabled them to live a way of life according to the elitist knightly ideal typical of the aristocratic segments of the society of that time.

KEY WORDS: Merchants. Cities. La Rioja. XVth-XVIth century. Economy. Patrimony. Way of life.

* El presente artículo forma parte de los resultados de un Proyecto de Investigación financiado por la Universidad de La Rioja (AP105/A2). 
El comercio y los mercaderes conformaron dos pilares fundamentales del desarrollo de las ciudades y villas del territorio riojano medieval. Ya desde el siglo XII y a lo largo del XIII se constata el destacado papel que las actividades mercantiles tuvieron para las economías urbanas, recibiendo los núcleos urbanos privilegios para la celebración de ferias y mercados ${ }^{1}$. De la misma forma, la documentación plenomedieval deja constancia de las actividades desplegadas en ciudades como Logroño, Nájera, Santo Domingo de la Calzada o Calahorra, por vecinos que a través del comercio y otros negocios igualmente productivos, se situaron en las posiciones más elevadas de la pirámide social de sus respectivas localidades, conformando una élite social que se fue organizando en un estado o estamento denominado ciudadano o ciudadano-ruano en ciudades tan importantes como Logroño, Nájera o Calahorra²

A finales de la Edad Media e inicios de la Moderna los mercaderes y hombres de negocio riojanos, seguían ostentando igualmente una posición destacada dentro del marco de convivencia social que conformaban las ciudades y las villas de este territorio. Ahora bien, la documentación de fines del siglo XV e inicios del XVI pone asimismo de manifiesto que se habían producido algunos cambios en su seno, motivados en parte porque su primacía había comenzado a ser cuestionada por otros sectores sociales, especialmente por los miembros del estado noble, algunos de cuyos representantes tampoco dudaron en dedicarse a las lucrativas actividades comerciales que tradicionalmente habían estado vinculadas a los miembros del estado ciudadano3.

A través de las siguientes páginas pretendemos acercarnos a las bases materiales de la riqueza de los mercaderes y hombres de negocio de las ciudades y

Principales abreviaturas utilizadas:

(A)rchivo de la (R)eal (Ch)ancillería de (V)alladolid; (A)rchivo (G)eneral de (S)imancas; (A)rchivo (H)istórico (N)acional; (A)rchivo (H)istórico (P)rovincial de (L)a (R)ioja; (A)rchivo (H)istórico (P)rovincial de (A)lava; (A)rchivo (M)unicipal de (A)rnedo; (A)rchivo (M)unicipal de (C)alahorra; (A)rchivo (M)unicipal de (H)aro; (A)rchivo (M)unicipal de (N)ájera; (A)rchivo (M)unicipal de (S)anto (D)omingo de la (C)alzada; (C)ámara de (C)astilla; (R)egistro de (R)eales (E)jecutorias; (P)leitos (C)iviles; (P)rotocolos (N)otariales; (P)ueblos; (F)enecidos; (O)lvidados; (C)asa y (S)itio (R)eales; (L)ibro de (C)uentas; (L)ibro de (A)ctas; (C)ontaduría (M)ayor de (C)uentas; (E)scribanía (M)ayor de (R)entas; (E)xpedientes de (H)acienda.

${ }^{1}$ MARTíneZ SOPENA, Pascual: «Logroño y las villas riojanas entre los siglos XII y XIV» en Historia de la ciudad de Logroño, Logroño, 1994, vol. 2, págs. 279-322, RUIZ DE LA PEÑA, Juan Ignacio: «La formación de la red urbana en el tramo riojano del Camino de Santiago y las colonizaciones francas (siglos XI-XIII)» en Actas de la Reunión Científica El fuero de Logroño y su época, Logroño, 1996, págs. 211-230 y CANTERA MONTENEGRO, Enrique: «Franquicias regias a ciudades y villas riojanas en el marco de la política repobladora de Alfonso X» en Berceo (Logroño) 114-115 (1988) págs. 105-118.

2 Goicolea Julián, Fco. Javier: El gobierno urbano en La Rioja en época medieval e inicios de la Edad Moderna (s. XIII-mediados del XVI), Logroño, 2004, págs. 15-38.

3 Goicolea Julián, Fco. Javier: «Sociedad y poder concejil. Una aproximación a la élite dirigente urbana de La Rioja Alta medieval» en Studia Historica Historia Medieval (Salamanca) 17 (1999) págs. 87-112. 
villas riojanas, siendo el objetivo del presente estudio el análisis de las actividades económicas que desplegaban, los patrimonios que fueron conformando, la transmisión de los mismos en el seno familiar, así como algunos aspectos relativos a su mentalidad. Hemos utilizado con este objetivo documentos de diferente procedencia que, a pesar de que no nos han permitido vislumbrar con la misma intensidad la realidad de todas las ciudades y villas riojanas, sí que pensamos que resultan bastante ilustrativos para el objeto de realizar una primera caracterización de los mercaderes riojanos que vivieron en las ciudades y villas de este territorio en el marco temporal propuesto.

\section{EL COMERCIO COMO FUENTE PRINCIPAL DE INGRESOS: DEL MERCADO LO- CAL A LOS NEGOCIOS INTERNACIONALES.}

"Que se an llamado y llamaban ciudadanos y ruanos porque los que asi se an llamado ciudadanos y ruanos ha visto que an bibido e bibian de sus haçiendas y tratos sin andar al canpo a trabajar, y se andavan paseando por las calles y ruas de la dicha çiudad»4.

Ésta era la definición que de los mercaderes y hombres de negocio de Nájera hacían sus contemporáneos de finales de la Edad Media, y que, como los demás mercaderes riojanos, desplegaron un amplio abanico de actividades comerciales, que abarcaban desde las más modestas de ámbito local y comarcal, hasta el comercio de amplio radio, interregional e incluso internacional.

Comenzaremos por las actividades más modestas, aunque no menos importantes, pues el abasto de productos básicos a los núcleos urbanos, se constituía en una tarea fundamental, ejercida por carniceros, tenderos o taberneros. Entre ellos, desde la segunda mitad del siglo XV nos encontramos a representantes de algunas de las más conocidas y poderosas familias de mercaderes de ciudades como Logroño y Nájera. En Logroño documentamos a los Moreno, concretamente a Fernando Moreno y Diego Moreno, quienes consta que se ocuparon de abastecer las tiendas de esta ciudad en los años finales del siglo $\mathrm{XV}^{5}$; mientras en Nájera esta labor de abasto fue desempeñada, entre otras, por la poderosa familia ciudadana de los Belorado. En efecto, en la segunda mitad de la centuria del cuatrocientos se puede documentar que Alonso González de Belorado abasteció la carnicería de la ciudad durante varios años, mientras su primo, Diego de Belorado, hacía lo mismo con la tienda del pescado ${ }^{6}$.

${ }^{4}$ A.R.Ch.V.: P.C. Escribanía de A. Rodríguez (F). C. 1020-1.

5 A.G.S.: C.S.R., leg. 44-8.

6 A.R.Ch.V.: P.C. Escribanía de A. Rodríguez (F). C. 1020-1 y Goicolea Julián, Fco. Javier: «La ciudad de Nájera en el tránsito de la Edad Media a la Moderna: El concejo, el señor y la sociedad política ciudadana» en Hispania (Madrid) 205 (2000) págs. 425-452. 
La relevancia social de los encargados de abastecer el mercado local de otras ciudades y villas riojanas es también conocida, aunque en la mayor parte de los casos contemos igualmente con información muy fragmentaria. Por lo que respecta a Santo Domingo de la Calzada, consta que un miembro de la familia Ocio, Miguel de Ocio, tuvo las tiendas de la ciudad en los años finales del siglo $\mathrm{XV}$, en 1508 fue Juan de Zaldo quien se obligó a abastecer las tabernas de la urbe, y hacia mediados del siglo XVI podemos documentar asimismo a representantes de la poderosa familia Ocio al frente del abasto de carne a la ciudad, concretamente a dos hijos del acaudalado mercader Cristóbal de Ocio ${ }^{7}$. En cuanto a Haro, en esta villa fue Martín Sánchez de Tricio el mercader que tuvo un especial protagonismo a fines de la Edad Media en el abastecimiento de la carnicería y de las tiendas de la villa, unos establecimientos dedicados sobre todo a la venta de pescado y de otros productos como aceite y candelas ${ }^{8}$. Y lo mismo se puede señalar para Rioja Baja, donde documentamos a los mercaderes Diego de Enciso y Juan García, encargados de abastecer de carne a la villa de Arnedo en 15079, o a ciertos vecinos ocupados en el abastecimiento de las tabernas de unos núcleos urbanos que producían menos vino y de peor calidad que en la zona altorriojana. Debemos trasladarnos también en este caso a las primeras décadas del siglo XVI, cuando Juan Ortiz de Bobadilla y Pedro Sevilla se encargaron de abastecer de vino las tabernas de Calahorra y Arnedo respectivamente ${ }^{10}$.

Ahora bien, los mercaderes también se ocupaban de procurar otro tipo de mercancías a sus convecinos de las ciudades y villas. Ésta era la función de los responsables de las mercerías, de las boticas o de las platerías existentes en los núcleos urbanos riojanos de finales de la Edad Media. En relación con los plateros, por ejemplo, hay constancia de que disponían de elevados niveles de renta, siendo ejercida esta actividad en algunas ciudades por miembros de destacadas familias ciudadanas. Son los casos de Diego de Salinas, hermano del alcaide de la ciudad de Nájera en la segunda mitad del siglo XV ${ }^{11}$, y sobre todo de Pedro de Enciso, miembro de la poderosa familia de mercaderes logroñeses del mismo apellido y que en 1493 se encontraba entre los diez mercaderes más ricos de la ciudad de Logroño, de acuerdo con su contribución a un préstamo demandado por los Reyes Católicos «para çierta armada» ${ }^{12}$. Otro Enciso, Juan, estaba al frente de la botica de la ciudad, y aunque su estatus económico no era del nivel

7 LÓPeZ De sIlanes, Ciriaco y SÁINZ RIPA, Eliseo: Colección Diplomática Calceatense. Archivo Catedral (1451-1499) y Archivo del Hospital (1431-1497), Logroño, 1992, doc. nº. 313, A.M.S.D.C.: L.A. 1508, sesión del 13 de julio y A.R.Ch.V.: P.C. Escribanía de Zarandona y Balboa (O). C. 8909, leg. 1.

8 Goicolea Julián, Fco. Javier: Haro: Una villa riojana del linaje Velasco a fines del Medievo, Logroño, 1999, págs. 103-110.

9 A.M.A.: L.C. 1507-1508, cuenta de ingresos de la villa.

10 A.M.C.: L.A. 1514, sesión del 17 de agosto y A.M.A.: L.A. 1533, sesión del 4 de mayo.

${ }^{11}$ Goicolea Julián, Fco. Javier: «La ciudad de Nájera..., o.c., págs. 425-452.

12 A.G.S.: C.S.R., leg. 44-8 y Tabla 1. 
del platero Pedro de Enciso ni mucho menos alcanzaba el nivel de los dos miembros más ricos del linaje, Juan Sánchez de Enciso «el viejo» y su hijo Pedro de Enciso, su aportación en 1493 al préstamo demandado por los Reyes Católicos no fue nada desdeñable.

TABla 1: CONTRIBUCiÓN DE LOS MERCADERES DE LOGROÑO EN EL PRÉSTAMO SOLICITADO POR LOS REYES CATÓLICOS EN 1493

\begin{tabular}{|l|l|}
\hline MERCADERES & CANTIDAD \\
\hline Juan SÁNCHEZ DE ENCISO (El viejo) & $13.000 \mathrm{mrs}$. \\
\hline Pedro DE ENCISO (Hijo de Juan Sánchez de Enciso) & $13.000 \mathrm{mrs}$. \\
\hline Cristóbal MORENO & $11.000 \mathrm{mrs}$. \\
\hline Fernando DE CASTRO & $9.000 \mathrm{mrs}$. \\
\hline Sancho LÓPEZ DE LA REDONDA & $9.000 \mathrm{mrs}$. \\
\hline Diego DE SESMA & $8.000 \mathrm{mrs}$. \\
\hline Rodrigo DE YANGUAS (El viejo) & $7.000 \mathrm{mrs}$. \\
\hline Martín DE ARRIAGA & $6.000 \mathrm{mrs}$. \\
\hline Pedro DE ENCISO, platero & $6.000 \mathrm{mrs}$. \\
\hline Pedro DE VIANA & $5.000 \mathrm{mrs}$. \\
\hline Fernando MARTÍNEZ DE NAVARRETE & $5.000 \mathrm{mrs}$. \\
\hline Juan DE PEÑARANDA & $5.000 \mathrm{mrs}$. \\
\hline Juan DE GAUNA & $4.000 \mathrm{mrs}$. \\
\hline GARCÍA (Yerno de Sancho López de La Redonda) & $4.000 \mathrm{mrs}$. \\
\hline Gómez DE SANTA GADEA & $4.000 \mathrm{mrs}$. \\
\hline Fernando DE VITORIA & $4.000 \mathrm{mrs}$. \\
\hline Juan (Hijo de Juan Rodríguez Aguado) & $4.000 \mathrm{mrs}$. \\
\hline Luis DE YANGUAS & $3.500 \mathrm{mrs}$. \\
\hline Juan DE ENCISO, boticario & $3.000 \mathrm{mrs}$. \\
\hline Pedro DE YANGUAS & $3.000 \mathrm{mrs}$. \\
\hline Gabriel DE VIANA & $3.000 \mathrm{mrs}$. \\
\hline Juan JUBERA & $3.000 \mathrm{mrs}$. \\
\hline Luis DE ALBELDA & $3.000 \mathrm{mrs}$. \\
\hline Pedro RODRÍGUEZ BARRÓN & $3.000 \mathrm{mrs}$. \\
\hline Diego MORENO (Hermano de Cristóbal Moreno) & $3.000 \mathrm{mrs}$. \\
\hline Lope DE VIANA & $3.000 \mathrm{mrs}$. \\
\hline Pedro DE ALFARO (Cuñado de Juan de Gauna) & $3.000 \mathrm{mrs}$. \\
\hline Rodrigo GARCÍA & $3.000 \mathrm{mrs}$. \\
\hline Luis LÓPEZ, platero & $3.000 \mathrm{mrs}$. \\
\hline Pedro DE SORIA & $2.500 \mathrm{mrs}$. \\
\hline Alonso MORENO (El mozo) & $2.500 \mathrm{mrs}$. \\
\hline Perucho de ZALDÍBAR & $2.000 \mathrm{mrs}$. \\
\hline & \\
\hline
\end{tabular}




\begin{tabular}{|l|l|}
\hline MERCADERES & CANTIDAD \\
\hline Fernando MORENO, tendero & $2.000 \mathrm{mrs}$. \\
\hline Diego MORENO, tendero & $2.000 \mathrm{mrs}$. \\
\hline Lope DÍAZ & $2.000 \mathrm{mrs}$. \\
\hline Juan DE CALAHORRA & $2.000 \mathrm{mrs}$. \\
\hline Diego DE HARO & $2.000 \mathrm{mrs}$. \\
\hline GAUNA (Sobrino de Juan de Gauna) & $2.000 \mathrm{mrs}$. \\
\hline Juan DE ORTIGOSA (Yerno de Juan de Mansilla) & $2.000 \mathrm{mrs}$. \\
\hline Diego, boticario & $2.000 \mathrm{mrs}$. \\
\hline Juan de ESTELLA & $2.000 \mathrm{mrs}$. \\
\hline Juan RODRÍGUEZ AGUADO & $2.000 \mathrm{mrs}$. \\
\hline ESPERANDEO & $2.000 \mathrm{mrs}$. \\
\hline Pedro de AZAGRA & $2.000 \mathrm{mrs}$. \\
\hline Fernando RUIZ DE LUMBRERAS & $1.500 \mathrm{mrs}$. \\
\hline García de VIANA, pellejero & $1.500 \mathrm{mrs}$. \\
\hline Diego de LA TORRE & $1.500 \mathrm{mrs}$. \\
\hline Diego LOBO & $1.500 \mathrm{mrs}$. \\
\hline Fernando de LA HAYA & $1.110 \mathrm{mrs}$. \\
\hline Beltrán DE CALAHORRA & $1.006 \mathrm{mrs}$. \\
\hline VILLOSLADA (Hijo del licenciado Lope Rodríguez) & $1.000 \mathrm{mrs}$. \\
\hline Alonso EL ROXO (El mozo) & $1.000 \mathrm{mrs}$. \\
\hline Sancho MARTíNEZ DE LOS ARCOS & $1.000 \mathrm{mrs}$. \\
\hline Enrique, mercero & $1.000 \mathrm{mrs}$. \\
\hline Juan de LA TORRE & $1.000 \mathrm{mrs}$. \\
\hline
\end{tabular}

FUENTE: A.G.S.: C.S.R., leg. 44-8.

Tampoco podían faltar en las ciudades riojanas las ventas de productos textiles, que sabemos que efectuaban los mercaderes de Logroño a vecinos y «foranos» a fines del siglo XV. Así consta en un documento de 1494, cuando los mercaderes logroñeses Diego de Villoslada, Diego de Haro, Alonso el Roxo, Juan de Gauna, Juan de la Torre, Alonso Moreno, Esperandeo y Antonio de Yanguas, fueron acusados de vender paños sin tundir a vecinos de Logroño y a «foranos», sin respetar la pragmática que sobre esta cuestión habían ordenado los Reyes Católicos ${ }^{13}$. Sin duda, y como también se puede constatar en Calahorra a través de las ventas de paños realizadas por el mercader Francisco Díaz en $1539^{14}$, existía una indudable vinculación de los mercaderes de estas ciudades

13 A.G.S.: C.C., P., leg. 10-198 y Iradiel Murugarren, Paulino: Evolución de la industria textil castellana en los siglos XIII-XVI. Factores de desarrollo, organización y costes de la producción manufacturera en Cuenca, Salamanca, 1974, págs. 136-137.

${ }_{14}$ A.H.P.L.R.: P.N. Escribanía de Diego Ibáñez. C. 356 (15-X-1539). 
con la venta y en algunos casos también con la producción de paños, como ponen de manifiesto las referencias a mercaderes «de facer paños» en Santo Domingo de la Calzada. En esta ciudad hay constancia de que en 1485 el mercader Juan Sánchez de Ocio había llegado a un acuerdo con el cabildo calceatense para construir un tirador en uno de sus solares, y dos años después sabemos que el mismo Juan Sánchez de Ocio había acudido a la ciudad francesa de Toulouse junto a su hijo, Sebastián de Ocio, para adquirir pastel ${ }^{15}$. Y entre los mercaderes «de facer paños» también se encontraban personajes procedentes de localidades cameranas, tales como Diego Sánchez, quien, nacido en Lumbreras, se había avecindado en Santo Domingo de la Calzada en el siglo XV ${ }^{16}$.

La venta de los productos textiles era, en consecuencia, uno de los principales negocios de los mercaderes riojanos en general y de los logroñeses en particular, tal y como queda confirmado en el registro de compra-ventas realizado por el escribano Cristóbal Rodríguez en 1535 ${ }^{17}$; un registro que, como podremos comprobar seguidamente, corrobora asimismo la ampliación del marco de negocio de los mercaderes logroñeses hacia un ámbito regional.

\section{TABLA 2: VENTAS EFECTUADAS POR MERCADERES DE LOGROÑO}

\begin{tabular}{|l|c|c|c|c|}
\hline FECHA & $\begin{array}{c}\text { MERCADERES } \\
\text { VENDEDORES }\end{array}$ & PRODUCTO & COMPRADORES & PRECIO \\
\hline $1535(21-\mathrm{I})$ & $\begin{array}{c}\text { Hernando de } \\
\text { Bazán }\end{array}$ & Paño y seda & $\begin{array}{c}\text { Juana Pérez, vecina de } \\
\text { Logroño }\end{array}$ & $18.750 \mathrm{mrs}$. \\
\hline $1535(28-\mathrm{II})$ & $\begin{array}{c}\text { Antonio de } \\
\text { Yanguas }\end{array}$ & Cierto paño & $\begin{array}{c}\text { Blas Quizán, vecino } \\
\text { de Navarrete }\end{array}$ & $7.208 \mathrm{mrs}$. \\
\hline $1535(4-\mathrm{III})$ & $\begin{array}{c}\text { Antonio de } \\
\text { Yanguas }\end{array}$ & Cierto paño & $\begin{array}{c}\text { Pedro de Moreda, } \\
\text { vecino de Navarrete }\end{array}$ & $29.578 \mathrm{mrs}$. \\
\hline $1535(16-\mathrm{III})$ & $\begin{array}{c}\text { Antonio de } \\
\text { Yanguas }\end{array}$ & Cierto paño & $\begin{array}{c}\text { Juan de Peñalva, } \\
\text { vecino de Autol }\end{array}$ & $4.724 \mathrm{mrs}$. \\
\hline
\end{tabular}

${ }^{15}$ Goicolea Julián, Fco. Javier: «Sociedad y relaciones de poder en una ciudad riojana a fines del Medievo: Santo Domingo de la Calzada» en Espacio, Tiempo y Forma, Historia Medieval (Madrid) 12 (1999) pág. 279. El pastel era una planta tintórea que proporcionaba un colorante azul a las prendas, y la ciudad de Toulouse controlaba una importante producción que se extendía en un área de cien kilómetros cuadrados (CASAdo Alonso, Hilario: El Triunfo de Mercurio. La Presencia Castellana en Europa (Siglos XV y XVI), Burgos, 2003, pág. 114).

${ }^{16}$ Goicolea Julián, Fco. Javier: «Sociedad y relaciones de poder..., o.c., pág. 277. El textil era, por lo demás, el sector artesanal que agrupaba a un mayor número de profesionales en las ciudades y villa riojanas en el tránsito de la Edad Media a la Moderna (Goicolea Julián, Fco. Javier: «Mundo urbano y actividades económicas en La Rioja Alta bajomedieval» en Espacio, Tiempo y Forma, Historia Medieval (Madrid) 11 (1998), págs. 259-269 y "Gobierno y sociedad en un núcleo urbano de La Rioja Baja: Calahorra (s. XIII-inicios del XVI)» en Espacio, Tiempo y Forma, Historia Medieval (Madrid) 16 (2003) págs. 107-150).

17 A.H.P.L.R.: P.N. Escribanía de Cristóbal Rodríguez. C. 473. 


\begin{tabular}{|c|c|c|c|c|}
\hline FECHA & $\begin{array}{l}\text { MERCADERES } \\
\text { VENDEDORES }\end{array}$ & PRODUCTO & COMPRADORES & PRECIO \\
\hline 1535 (18-III) & \begin{tabular}{|c|} 
Pedro Fernández \\
de Navarrete
\end{tabular} & Cierto paño & $\begin{array}{c}\text { Francisco López, sas- } \\
\text { tre de Logroño }\end{array}$ & $43.800 \mathrm{mrs}$ \\
\hline 1535 (23-III) & $\begin{array}{l}\text { Antonio de } \\
\text { Yanguas }\end{array}$ & Cierto paño & $\begin{array}{l}\text { Juan de Diago, vecino } \\
\text { de la villa de Préjano }\end{array}$ & $1.593 \mathrm{mrs}$. \\
\hline 1535 (23-III) & $\begin{array}{c}\text { Pedro Fernández } \\
\text { de Navarrete }\end{array}$ & Cierto paño & $\begin{array}{l}\text { Francisco Bravo, tun- } \\
\text { didor de la ciudad de } \\
\text { Logroño }\end{array}$ & $27.000 \mathrm{mrs}$ \\
\hline 1535 (24-III) & \begin{tabular}{|c|}
$\begin{array}{c}\text { Pedro Fernández } \\
\text { de Navarrete }\end{array}$ \\
\end{tabular} & $\begin{array}{l}\text { Tres paños } \\
\text { tunes }\end{array}$ & $\begin{array}{l}\text { Pedro de Lanciego, } \\
\text { sastre de Logroño }\end{array}$ & $26.100 \mathrm{mrs}$. \\
\hline 1535 (13-IV) & $\begin{array}{c}\text { Antonio de } \\
\text { Yanguas }\end{array}$ & Cierto paño & $\begin{array}{c}\text { Juan Ramírez, vecino } \\
\text { de Arnedo }\end{array}$ & $6.750 \mathrm{mrs}$ \\
\hline $1535(3-V)$ & $\begin{array}{c}\text { Diego de Ribera } \\
\text { «el viejo» }\end{array}$ & $\begin{array}{c}6 \text { varas y } 1 / 3 \text { de } \\
\text { contray de } \\
\text { Flandes }\end{array}$ & $\begin{array}{l}\text { Pedro de Aragón y } \\
\text { María, vecinos de } \\
\text { Fuenmayor }\end{array}$ & 2.686 mrs. \\
\hline $1535(11-V)$ & $\begin{array}{c}\text { Diego de Ribera } \\
\text { «el viejo» }\end{array}$ & $\begin{array}{c}17 \text { varas de } \\
\text { paño de pardillo }\end{array}$ & $\begin{array}{l}\text { Pedro Melón «el mo- } \\
\text { zo», morador en el } \\
\text { Cortijo, y Martín } \\
\text { Benito, vecino de } \\
\text { Fuenmayor }\end{array}$ & $2.023 \mathrm{mrs}$. \\
\hline 1535 (19-VI) & \begin{tabular}{|c|} 
Juan de Armen- \\
tia \\
\end{tabular} & $\begin{array}{c}2 \text { yunques de } \\
\text { herrero }\end{array}$ & $\begin{array}{l}\text { Juan Clemente, herre- } \\
\text { ro de Alesón }\end{array}$ & 3.000 mrs. \\
\hline $1535(22-\mathrm{VI})$ & $\begin{array}{l}\text { Hernando de } \\
\text { Bazán }\end{array}$ & $\begin{array}{l}28 \text { fanegas de } \\
\text { trigo }\end{array}$ & $\begin{array}{l}\text { Juan del Valle, Do- } \\
\text { mingo Martínez y } \\
\text { Juan Bazo, vecinos de } \\
\text { Vadillos, y Juan Mar- } \\
\text { tínez de Nieva, vecino } \\
\text { de San Llorente } \\
\end{array}$ & 3.876 mrs. \\
\hline 1535 & $\begin{array}{l}\text { Hernando de } \\
\text { Bazán }\end{array}$ & Varas de paño & $\begin{array}{l}\text { Juan de Castroviejo y } \\
\text { Francisco de la Torre, } \\
\text { vecinos de Navarrete }\end{array}$ & 17. $672 \mathrm{mrs}$. \\
\hline 1535 (21-VII) & $\begin{array}{l}\text { Antonio de } \\
\text { Yanguas }\end{array}$ & $\begin{array}{l}10 \text { varas de } \\
\text { ultrafín }\end{array}$ & $\begin{array}{l}\text { Juanes de Aguilar y } \\
\text { Pedro de Madriz, } \\
\text { vecinos de Viana }\end{array}$ & $4.225 \mathrm{mrs}$. \\
\hline 1535 (29-VII) & $\begin{array}{l}\text { Antonio de } \\
\text { Yanguas }\end{array}$ & $\begin{array}{c}3,5 \text { varas de } \\
\text { contray de } \\
\text { Flandes }\end{array}$ & $\begin{array}{l}\text { Pedro de Mondragón y } \\
\text { Miguel de Elgueta, } \\
\text { carpinteros de Logroño }\end{array}$ & 2.860 mrs. \\
\hline 1535 (3-VIII) & $\begin{array}{c}\text { Juan de Pedroso } \\
\text { y Andrés Galle- } \\
\text { go }\end{array}$ & $\begin{array}{c}10 \text { varas de } \\
\text { refino de Sego- } \\
\text { via y } 3,5 \text { varas } \\
\text { de veintenos de } \\
\text { Segovia }\end{array}$ & $\begin{array}{l}\text { Cristóbal de Celis, y } \\
\text { Juan López, hombres } \\
\text { de armas de la capita- } \\
\text { nía del marqués de } \\
\text { Berlanga }\end{array}$ & 11. $352 \mathrm{mrs}$ \\
\hline 1535 (10-VIII) & $\begin{array}{c}\text { Juan de Pedroso } \\
\text { y Andrés Galle- } \\
\text { go }\end{array}$ & $\begin{array}{c}3,25 \text { varas de } \\
\text { Londres, } 1 \text { vara } \\
\text { de contray, y } 1 / 3 \\
\text { de terciopelo }\end{array}$ & $\begin{array}{l}\text { Diego Sáenz de Pa- } \\
\text { yueta y Pedro Sáenz } \\
\text { de Payueta, vecinos } \\
\text { de Laguardia }\end{array}$ & $2.106 \mathrm{mrs}$. \\
\hline
\end{tabular}




\begin{tabular}{|c|c|c|c|c|}
\hline FECHA & $\begin{array}{l}\text { MERCADERES } \\
\text { VENDEDORES }\end{array}$ & PRODUCTO & COMPRADORES & PRECIO \\
\hline 1535 (10-VIII) & $\begin{array}{l}\text { Antonio de } \\
\text { Yanguas }\end{array}$ & $\begin{array}{c}4,5 \text { varas de } \\
\text { paño gris, } 1 \\
\text { vara y } 3 / 4 \text { de } \\
\text { cordelán negro } \\
\text { de Toledo }\end{array}$ & $\begin{array}{l}\text { Fco. de Colmenares, } \\
\text { vecino de Quel }\end{array}$ & $1.926,5 \mathrm{mrs}$ \\
\hline 1535 (10-VIII) & $\begin{array}{l}\text { Antonio de } \\
\text { Yanguas }\end{array}$ & \begin{tabular}{|c|}
1 vara y $1 / 4$ de \\
contray de \\
Flandes, 3 varas \\
y $2 / 3$ de Perpi- \\
ñán dorado y 1 \\
vara de engaza- \\
do de la tierra \\
\end{tabular} & $\begin{array}{l}\text { Juan García, vecino } \\
\text { de El Villar de Arnedo }\end{array}$ & $2.231 \mathrm{mrs}$. \\
\hline 1535 (11-VIII) & $\begin{array}{l}\text { Juan de Pedroso } \\
\text { y Andrés Galle- } \\
\text { go }\end{array}$ & $\begin{array}{c}9 \text { varas de ultra- } \\
\text { fín }\end{array}$ & $\begin{array}{l}\text { Fco. de Mero y Pedro } \\
\text { de Mercado, miembros } \\
\text { de la capitanía de don } \\
\text { Fadrique de Acuña }\end{array}$ & $3.375 \mathrm{mrs}$. \\
\hline 1535 (17-VIII) & $\begin{array}{l}\text { Antonio de } \\
\text { Yanguas }\end{array}$ & $\begin{array}{l}4 \text { varas de Ruán, } \\
5 \text { varas y } 1 / 4 \text { de } \\
\text { refino de Sego- } \\
\text { via, } 3 \text { varas y } \\
1 / 4 \text { de Londres, } \\
4 \text { varas de ultra- } \\
\text { fín y } 2 / 3 \text { de } \\
\text { terciopelo } \\
\end{array}$ & $\begin{array}{l}\text { Diego Moreno, vecino } \\
\text { de la villa de Los Ar- } \\
\text { cos }\end{array}$ & $9.851 \mathrm{mrs}$. \\
\hline 1535 (17-VIII) & $\begin{array}{c}\text { Diego de Ribera } \\
\text { «el viejo» }\end{array}$ & $\begin{array}{c}1 \text { pieza de paño } \\
\text { de ultrafín y } 2 \\
\text { varas }\end{array}$ & $\begin{array}{c}\text { Jimeno Bretón, sastre } \\
\text { de Logroño }\end{array}$ & $7.276 \mathrm{mrs}$. \\
\hline 1535 (18-VIII) & Martín de Urtao & $\begin{array}{l}12 \text { cueros de } \\
\text { bueyes y vacas } \\
\text { adobados de } \\
\text { Inglaterra }\end{array}$ & $\begin{array}{l}\text { Pedro de la Puebla, } \\
\text { zapatero de Logroño }\end{array}$ & $7.258 \mathrm{mrs}$. \\
\hline 1535 (18-VIII) & $\begin{array}{c}\text { Fco. de Tejada y } \\
\text { Pedro de Enciso } \\
\text { Navarrete }\end{array}$ & $\begin{array}{c}4 \text { paños tunes, } 3 \\
\text { sellados y } 1 \\
\text { copado }\end{array}$ & Fco. López sastre & $35.400 \mathrm{mrs}$. \\
\hline 1535 (20-VIII) & $\begin{array}{l}\text { Hernando de } \\
\text { Bazán }\end{array}$ & $\begin{array}{c}2 \text { varas y } 3 / 4 \text { de } \\
\text { paño blanco de } \\
\text { Toledo, } 2,5 \text { varas } \\
\text { de faseta de In- } \\
\text { glaterra, } 3 \text { varas } \\
\text { de grana de To- } \\
\text { ledo, } 5,25 \text { varas } \\
\text { de terciopelo, } 4 \\
\text { varas de damasco } \\
\text { anaranjado, } 2,25 \\
\text { varas de angeo y } \\
2 \text { varas de raso }\end{array}$ & $\begin{array}{c}\text { Remón de Esparza, } \\
\text { hombre de armas de } \\
\text { la capitanía de don } \\
\text { Diego }\end{array}$ & $10.636 \mathrm{mrs}$. \\
\hline
\end{tabular}




\begin{tabular}{|c|c|c|c|c|}
\hline FECHA & $\begin{array}{l}\text { MERCADERES } \\
\text { VENDEDORES }\end{array}$ & PRODUCTO & COMPRADORES & PRECIO \\
\hline 1535 (23-VIII) & $\begin{array}{l}\text { Hernando de } \\
\text { Bazán }\end{array}$ & $\begin{array}{c}\text { 7,5 varas de } \\
\text { paño de Londres } \\
\text { gris }\end{array}$ & $\begin{array}{l}\text { Diego de Bustillo, } \\
\text { hombre de armas de } \\
\text { la capitanía de don } \\
\text { Miguel de Velasco }\end{array}$ & $3.187 \mathrm{mrs}$. \\
\hline 1535 (25-VIII) & $\begin{array}{l}\text { Juan de Pedroso } \\
\text { y Andrés Gallego }\end{array}$ & $\begin{array}{l}5 \text { varas de refi- } \\
\text { no, } 4 \text { varas de } \\
\text { Perpiñán leona- } \\
\text { do y } 2 \text { varas de } \\
\text { terciopelo }\end{array}$ & $\begin{array}{c}\text { Lope Cornejo, hombre } \\
\text { de armas de la capita- } \\
\text { nía de don Fadrique } \\
\text { de Acuña }\end{array}$ & $6.802 \mathrm{mrs}$. \\
\hline 1535 (26-VIII) & Martín de Urtao & $\begin{array}{c}13 \text { cueros de } \\
\text { bueyes y vacas } \\
\text { de Inglaterra }\end{array}$ & $\begin{array}{l}\text { Fco. de Angulo, zapa- } \\
\text { tero de Logroño }\end{array}$ & $7.500 \mathrm{mrs}$ \\
\hline 1535 (27-VIII) & $\begin{array}{l}\text { Hernando de } \\
\text { Bazán }\end{array}$ & $\begin{array}{c}7 \text { varas de con- } \\
\text { tray de Flandes, } \\
3,5 \text { varas de } \\
\text { Perpiñán, media } \\
\text { vara de terciope- } \\
\text { lo, y } 2 / 3 \text { de paño } \\
\text { verde oscuro }\end{array}$ & $\begin{array}{l}\text { Pedro Navarro, vecino } \\
\text { de Agoncillo }\end{array}$ & $4.742 \mathrm{mrs}$ \\
\hline 1535 (31-VIII) & $\begin{array}{l}\text { Antonio de } \\
\text { Yanguas }\end{array}$ & $\begin{array}{l}5 \text { varas de vein- } \\
\text { tidosenos de } \\
\text { Segovia y } 1 \text { vara } \\
\text { de uscarán }\end{array}$ & $\begin{array}{c}\text { Juan de Ausejo, veci- } \\
\text { no de Autol }\end{array}$ & $2.074 \mathrm{mrs}$ \\
\hline 1535 (31-VIII) & $\begin{array}{l}\text { Antonio de } \\
\text { Yanguas }\end{array}$ & $\begin{array}{l}4 \text { varas de vein- } \\
\text { tidosenos de } \\
\text { Segovia }\end{array}$ & $\begin{array}{c}\text { Juan de Toledo, veci- } \\
\text { no de Autol }\end{array}$ & $1.632 \mathrm{mrs}$. \\
\hline 1535 (1-IX) & $\begin{array}{l}\text { Antonio de } \\
\text { Yanguas }\end{array}$ & \begin{tabular}{|c}
3 varas de refino \\
de Segovia, 2 \\
varas de Perpiñán, \\
1 vara y $3 / 4$ de \\
estamete de Tole- \\
do blanco, y 2 \\
varas de brocado \\
\end{tabular} & $\begin{array}{c}\text { Fco. de Grandes, } \\
\text { teniente de alcaide, } \\
\text { vecino de la villa de } \\
\text { Ocón }\end{array}$ & $3.213 \mathrm{mrs}$ \\
\hline 1535 (2-IX) & Bertol de Peralta & 340 carneros & $\begin{array}{c}\text { Fco. de Ayala, vecino } \\
\text { de Navarrete }\end{array}$ & $79.790 \mathrm{mrs}$. \\
\hline 1535 (2-IX) & Martín de Urtao & $\begin{array}{c}6 \text { cueros adoba- } \\
\text { dos de bueyes } \\
\text { de Inglaterra }\end{array}$ & $\begin{array}{l}\text { Juan Morales, zapate- } \\
\text { ro de Calahorra }\end{array}$ & $3.570 \mathrm{mrs}$ \\
\hline 1535 (4-IX) & $\begin{array}{c}\text { Juan de Armen- } \\
\text { tia }\end{array}$ & $\begin{array}{c}130 \text { quintales de } \\
\text { hierro }\end{array}$ & $\begin{array}{c}\text { Sebastián de Cabrejas, } \\
\text { vecino de la ciudad de } \\
\text { Soria }\end{array}$ & $53.170 \mathrm{mrs}$. \\
\hline 1535 (7-IX) & $\begin{array}{l}\text { Antonio de } \\
\text { Yanguas }\end{array}$ & $\begin{array}{c}7,5 \text { varas de } \\
\text { veintenos de } \\
\text { Segovia al pelo y } \\
\text { media vara de } \\
\text { terciopelo }\end{array}$ & $\begin{array}{c}\text { Fco. de Antezana, } \\
\text { vecino de la villa de } \\
\text { Alfaro }\end{array}$ & $2.176 \mathrm{mrs}$ \\
\hline
\end{tabular}




\begin{tabular}{|c|c|c|c|c|}
\hline FECHA & $\begin{array}{l}\text { MERCADERES } \\
\text { VENDEDORES }\end{array}$ & PRODUCTO & COMPRADORES & PRECIO \\
\hline 1535 (15-IX) & Alonso el Roxo & $\begin{array}{l}17 \text { fanegas de } \\
\text { trigo }\end{array}$ & $\begin{array}{c}\text { Pedro de Falces y } \\
\text { Juan Benito, morado- } \\
\text { res en Lardero }\end{array}$ & $2.551 \mathrm{mrs}$. \\
\hline 1535 (17-IX) & $\begin{array}{l}\text { Juan de Pedroso } \\
\text { y Andrés Gallego }\end{array}$ & $\begin{array}{l}6 \text { varas de Lon- } \\
\text { dres morados y } \\
1 / 3 \text { de terciopelo }\end{array}$ & $\begin{array}{c}\text { Juan de Fiñana y Juan } \\
\text { Pérez de Bargota, del } \\
\text { reino de Navarra }\end{array}$ & $3.290 \mathrm{mrs}$. \\
\hline 1535 (21-IX) & $\begin{array}{l}\text { Hernando de } \\
\text { Bazán }\end{array}$ & \begin{tabular}{|c|}
4 varas de con- \\
tray, 3 varas y \\
tercia de brune- \\
ta, 1 sesma de \\
terciopelo y \\
media vara de \\
verde oscuro \\
\end{tabular} & $\begin{array}{c}\text { Pedro de García Her- } \\
\text { náez y Pedro Romero, } \\
\text { moradores de Villa- } \\
\text { mediana }\end{array}$ & $2.558 \mathrm{mrs}$. \\
\hline 1535 (21-IX) & $\begin{array}{l}\text { Juan de Pedroso } \\
\text { y Andrés Gallego }\end{array}$ & \begin{tabular}{|c|}
3,25 varas de \\
Londres, 4 varas \\
de veintidosenos \\
y $2 / 3$ de verde \\
\end{tabular} & $\begin{array}{l}\text { Juan de la Peña y Fco. } \\
\text { Ruiz, vecinos de En- } \\
\text { trena }\end{array}$ & $2.426 \mathrm{mrs}$. \\
\hline 1535 (21-IX) & $\begin{array}{l}\text { Juan de Pedroso } \\
\text { y Andrés Gallego }\end{array}$ & $\begin{array}{l}7 \text { varas de ultra- } \\
\text { fín y } 1 \text { sesma de } \\
\text { terciopelo }\end{array}$ & $\begin{array}{c}\text { Sancho Ruiz y Diego } \\
\text { Hernández de Esqui- } \\
\text { de, vecinos de La- } \\
\text { guardia } \\
\end{array}$ & $2.761 \mathrm{mrs}$. \\
\hline $1535(14-X)$ & $\begin{array}{l}\text { Juan de Pedroso } \\
\text { y Andrés Gallego }\end{array}$ & \begin{tabular}{|c} 
Resto de 3,25 \\
varas de Londres \\
morados, 3,25 \\
varas de brune- \\
ta, $2 / 3$ de verde \\
\end{tabular} & $\begin{array}{c}\text { Juan Redondo y Mi- } \\
\text { guel Redondo, vecinos } \\
\text { de Ausejo }\end{array}$ & $1.468 \mathrm{mrs}$. \\
\hline $1535(15-X)$ & $\begin{array}{l}\text { Bernardino de } \\
\text { San Pedro }\end{array}$ & $\begin{array}{c}40 \text { fanegas de } \\
\text { trigo }\end{array}$ & $\begin{array}{c}\text { Rodrigo de Viñas, } \\
\text { Pedro de la Puerta } \\
\text { Vieja, Nicolás de True- } \\
\text { ba y Miguel Navarro, } \\
\text { vecinos de Logroño }\end{array}$ & $5.440 \mathrm{mrs}$. \\
\hline $1535(16-X)$ & $\begin{array}{l}\text { Bernardino de } \\
\text { San Pedro }\end{array}$ & $\begin{array}{c}20 \text { fanegas de } \\
\text { trigo }\end{array}$ & $\begin{array}{c}\text { Juan Fraile y Pedro de } \\
\text { Salinas, vecinos de } \\
\text { Logroño }\end{array}$ & $2.720 \mathrm{mrs}$. \\
\hline $1535(18-X)$ & $\begin{array}{l}\text { Antonio de } \\
\text { Yanguas }\end{array}$ & \begin{tabular}{|c|}
$\begin{array}{c}7 \text { varas de paño } \\
\text { pardo }\end{array}$ \\
\end{tabular} & $\begin{array}{l}\text { Sebastián Gascón, } \\
\text { vecino de Quel }\end{array}$ & 952 mrs. \\
\hline $1535(22-\mathrm{X})$ & $\begin{array}{l}\text { Antonio de } \\
\text { Yanguas }\end{array}$ & \begin{tabular}{|c|} 
Resta de 6 varas \\
de contray de \\
Flandes y 2 \\
varas de rosados \\
de Palencia \\
\end{tabular} & $\begin{array}{l}\text { Fco. de Zamudio y } \\
\text { Diego Gómez, mora- } \\
\text { dores en Elciego }\end{array}$ & $2.420 \mathrm{mrs}$. \\
\hline $1535(25-X)$ & $\begin{array}{l}\text { Bernardino de } \\
\text { San Pedro }\end{array}$ & $\begin{array}{c}25 \text { fanegas de } \\
\text { trigo }\end{array}$ & $\begin{array}{c}\text { Juan Gutiérrez de Espi- } \\
\text { nosa, Juan de Lodosa y } \\
\text { Antonio de Belorado, } \\
\text { vecinos de Logroño }\end{array}$ & $3.400 \mathrm{mrs}$ \\
\hline
\end{tabular}




\begin{tabular}{|c|c|c|c|c|}
\hline FECHA & $\begin{array}{l}\text { MERCADERES } \\
\text { VENDEDORES }\end{array}$ & PRODUCTO & COMPRADORES & PRECIO \\
\hline $1535(25-\mathrm{X})$ & $\begin{array}{l}\text { Bernardino de } \\
\text { San Pedro }\end{array}$ & $\begin{array}{l}18 \text { fanegas de } \\
\text { trigo }\end{array}$ & $\begin{array}{l}\text { Juan Beltrán caldere- } \\
\text { ro y Diego Beltrán, } \\
\text { vecinos de Logroño }\end{array}$ & $2.448 \mathrm{mrs}$ \\
\hline $1535(25-\mathrm{X})$ & Juan de Enciso & $\begin{array}{c}150,5 \text { cargas de } \\
\text { uva en rama }\end{array}$ & $\begin{array}{l}\text { Pedro Fernández de } \\
\text { Navarrete, vecino de } \\
\text { Logroño }\end{array}$ & $11.438 \mathrm{mrs}$ \\
\hline $1535(28-X)$ & $\begin{array}{l}\text { Antonio de } \\
\text { Yanguas }\end{array}$ & Paños & $\begin{array}{c}\text { Diego Bretón y Juan } \\
\text { Bretón, vecinos de } \\
\text { Arnedo y moradores } \\
\text { en Bergasa }\end{array}$ & $\begin{array}{c}13.477,5 \\
\text { mrs. }\end{array}$ \\
\hline 1535 (2-XI) & $\begin{array}{l}\text { Antonio de } \\
\text { Yanguas }\end{array}$ & $\begin{array}{c}3,25 \text { varas de } \\
\text { Londres mora- } \\
\text { dos, } 7 \text { varas de } \\
\text { bruneta, } 2 / 3 \text { de } \\
\text { verde oscuro } \\
\end{array}$ & $\begin{array}{l}\text { Pedro Herrero y Juan } \\
\text { Herrero, vecinos de la } \\
\text { villa de Arnedo, mo- } \\
\text { radores en Carbonera }\end{array}$ & $3.123 \mathrm{mrs}$ \\
\hline 1535 (9-XI) & Pedro Sánchez & $\begin{array}{c}3 \text { varas de bru- } \\
\text { neta }\end{array}$ & $\begin{array}{c}\text { Juan Francés y Juan } \\
\text { García, vecinos de } \\
\text { Ausejo }\end{array}$ & $612 \mathrm{mrs}$. \\
\hline $1535(15-\mathrm{XI})$ & $\begin{array}{l}\text { Antonio de } \\
\text { Yanguas }\end{array}$ & Cierto paño & $\begin{array}{l}\text { Pedro Martínez, veci- } \\
\text { no de la villa de Quel }\end{array}$ & 4.016 mrs. \\
\hline 1535 (19-XI) & $\begin{array}{l}\text { Antonio de } \\
\text { Yanguas }\end{array}$ & Cierto paño & $\begin{array}{l}\text { Juan Díaz, vecino de } \\
\text { la villa de Arnedo }\end{array}$ & $2.982 \mathrm{mrs}$ \\
\hline $1535(22-\mathrm{XI})$ & García de Soria & $\begin{array}{l}250 \text { cántaras de } \\
\text { vino tinto de la } \\
\text { cosecha del año } \\
\end{array}$ & $\begin{array}{l}\text { Felipe de Salvatierra, } \\
\text { vecino de Logroño }\end{array}$ & $12.000 \mathrm{mrs}$. \\
\hline 1535 (7-XII) & $\begin{array}{l}\text { Antonio de } \\
\text { Yanguas }\end{array}$ & Paños & $\begin{array}{c}\text { Hernán Martínez de } \\
\text { Layasa, vecino de } \\
\text { Arnedo }\end{array}$ & $5.885 \mathrm{mrs}$ \\
\hline 1535 (7-XII) & $\begin{array}{l}\text { Antonio de } \\
\text { Yanguas }\end{array}$ & Paños & $\begin{array}{c}\text { Juan Morcuero, veci- } \\
\text { no de la villa de Ar- } \\
\text { nedo }\end{array}$ & $5.202,5 \mathrm{mrs}$. \\
\hline 1535 (7-XII) & $\begin{array}{l}\text { Antonio de } \\
\text { Yanguas }\end{array}$ & Paños & $\begin{array}{c}\text { Juan Martínez de } \\
\text { Layasa, vecino de la } \\
\text { villa de Arnedo }\end{array}$ & $5.728 \mathrm{mrs}$ \\
\hline 1535 (7-XII) & $\begin{array}{l}\text { Antonio de } \\
\text { Yanguas }\end{array}$ & Paños & $\begin{array}{l}\text { Rodrigo Bretón, veci- } \\
\text { no de la villa de Ar- } \\
\text { nedo }\end{array}$ & $3.005 \mathrm{mrs}$ \\
\hline 1535 (9-XII) & Pedro Sánchez & Paños & $\begin{array}{c}\text { Domingo de Ormáiz- } \\
\text { tegui, vecino de la } \\
\text { villa de Peralta }\end{array}$ & $23.781 \mathrm{mrs}$ \\
\hline 1535 (14-XII) & $\begin{array}{l}\text { Hernando de } \\
\text { Bazán }\end{array}$ & Paños & $\begin{array}{l}\text { Juan Ruiz de Robres, } \\
\text { vecino de la villa de } \\
\text { Murillo de Río Leza }\end{array}$ & $1.665 \mathrm{mrs}$. \\
\hline
\end{tabular}




\begin{tabular}{|l|c|c|c|c|}
\hline FECHA & $\begin{array}{c}\text { MERCADERES } \\
\text { VendEDORES }\end{array}$ & Producto & COMPRADORES & PreCIO \\
\hline $1535(15-\mathrm{XII})$ & $\begin{array}{c}\text { Antonio de } \\
\text { Yanguas }\end{array}$ & Paños & $\begin{array}{c}\text { Pedro de Amurrio, } \\
\text { vecino de la ciudad de } \\
\text { Calahorra }\end{array}$ & $2.000 \mathrm{mrs}$. \\
\hline $1535(31-\mathrm{XII})$ & $\begin{array}{c}\text { Juan de Pedroso } \\
\text { y Andrés Gallego }\end{array}$ & Paños & $\begin{array}{c}\text { Juan Tomás, morador } \\
\text { en Sotés, vecino de } \\
\text { Navarrete }\end{array}$ & $2.805 \mathrm{mrs.}$ \\
\hline
\end{tabular}

Fuente: A.H.P.L.R.: P.N. Escribanía de Cristóbal Rodríguez. C. 473.

Los mercaderes logroñeses que se registraron vendiendo paños en la escribanía de Cristóbal Rodríguez, fueron Hernando de Bazán, Antonio de Yanguas, Pedro Fernández de Navarrete, Diego de Ribera «el viejo», Juan de Pedroso, Andrés Gallego, Francisco de Tejada, Pedro de Enciso y Pedro Sánchez. Todos ellos vendían su mercancía textil en unas cuantías por venta que oscilaron entre los 43.800 maravedís que pagó el sastre de Logroño, Francisco López, al mercader Pedro Fernández de Navarrete, y los 612 maravedís que pagaron dos vecinos de Ausejo al mercader Pedro Sánchez. En algunos casos se puede conocer también la calidad del paño, poniéndose en venta varas de pardillo, contray, terciopelo, damasco, seda, ultrafín, brocado, bruneta, etc., así como su procedencia, de ciudades del Reino como Segovia, Palencia y Toledo, y de centros de producción internacionales como Perpiñán, Ruán, Flandes e Inglaterra (Londres). Los compradores eran, por su parte, vecinos de Logroño y de las aldeas de su alfoz; de otras localidades riojanas como Navarrete, Autol, Préjano, Arnedo, Fuenmayor, Laguardia, Quel, Agoncillo, Ocón, Alfaro, Entrena, Ausejo, Murillo o Calahorra; de villas navarras del entorno como Viana, Los Arcos o Peralta; y asimismo destacaban entre los compradores miembros de diferentes capitanías como las del marqués de Berlanga, don Fadrique de Acuña o don Miguel de Velasco.

Junto a las ventas de paños también se registraban en menor medida ventas de otros productos como trigo, cueros, carneros, uva, o los 130 quintales de hierro que Juan de Armentia vendió a un vecino de Soria por 53.170 maravedís. Todo lo cual se completaba con las compras que protagonizaron los mercaderes Logroñeses que utilizaron en 1535 el registro del escribano Cristóbal Rodríguez (ver Tabla 3). En este caso los mercaderes protagonistas fueron los ya conocidos Hernando de Bazán, Diego de Ribera «el viejo», Juan de Pedroso, Andrés Gallego, Antonio de Yanguas, Pedro de Enciso y Pedro Sánchez, a quienes se sumaron además Francisco de Navarrete, Hernando de Soria y Diego de Yanguas. Entre sus adquisiciones sobresalían diversas partidas de lana churra, destinadas probablemente a los mercados locales y regionales, y lanas estremeñas, blancas y finas de alta calidad cuyo objetivo debía ser la exportación. En ambos casos la lana era comprada a productores de localidades riojanas, como Autol, Quel, Albelda, Ocón, Murillo, Alfaro o Calahorra; riojano- 
cameranas como Almarza, Pinillos, Laguna o Gallinero; y sorianas ${ }^{18}$. Concretamente fue la compra de lana efectuada por los mercaderes Hernando de Soria y Diego de Yanguas a un vecino de la localidad soriana de Yanguas, la que supuso un desembolso de dinero más importante, ascendiendo las 930 arrobas de lana que adquirieron a 409.200 maravedís $^{19}$. Y junto a los mercaderes logroñeses, también documentamos a mercaderes de Calahorra y Santo Domingo de la Calzada efectuando compras de lana, como las realizadas por el ya citado mercader calagurritano, Francisco Díaz, el 21 de junio de $1540^{20}$, o las efectuadas algunos años antes por los mercaderes calceatenses Pedro de Ocio y Pedro de Anguiano, quienes según una ejecutoria judicial fechada en 1518, habían sido demandados por el vecino de Yanguas, Antón Sánchez, por no haber cumplido con la obligación de pagar las lanas churras y estremeñas que este vecino soriano les había vendido ${ }^{21}$.

TABLA 3: COMPRAS EFECTUADAS POR MERCADERES DE LOGROÑO

\begin{tabular}{|c|c|c|c|c|}
\hline FECHA & $\begin{array}{l}\text { MERCADERES } \\
\text { COMPRADORES }\end{array}$ & PRODUCTO & VENDEDORES & CuANTÍA \\
\hline $1535(18-\mathrm{I})$ & $\begin{array}{l}\text { Hernando de } \\
\text { Bazán }\end{array}$ & $\begin{array}{c}8 \text { arrobas de lana } \\
\text { buena }\end{array}$ & $\begin{array}{c}\text { Juan Valiente, } \\
\text { vecino de Almarza } \\
\text { de Cameros }\end{array}$ & $3.545 \mathrm{mrs}$. \\
\hline 1535 (23-III) & $\begin{array}{c}\text { Diego de Ribera } \\
\text { «el viejo» }\end{array}$ & $\begin{array}{c}60 \text { arrobas de } \\
\text { lana buena }\end{array}$ & $\begin{array}{l}\text { Juan Andrés, veci- } \\
\text { no de Sojuela }\end{array}$ & $18.360 \mathrm{mrs}$. \\
\hline 1535 (5-VII) & $\begin{array}{l}\text { Hernando de } \\
\text { Bazán }\end{array}$ & $\begin{array}{c}5 \text { arrobas de lana } \\
\text { buena, blanca y } \\
\text { fina }\end{array}$ & $\begin{array}{l}\text { Martín Fernández y } \\
\text { Martín Cámara, } \\
\text { vecinos de Pinillos } \\
\text { de los Cameros }\end{array}$ & $2.000 \mathrm{mrs}$. \\
\hline 1535 (7-VIII) & $\begin{array}{l}\text { Hernando de } \\
\text { Bazán }\end{array}$ & 5 arrobas de lana & $\begin{array}{l}\text { Martín Jiménez, } \\
\text { vecino de Cabezón } \\
\text { de los Cameros }\end{array}$ & - \\
\hline 1535 (14-VIII) & $\begin{array}{l}\text { Hernando de } \\
\text { Bazán }\end{array}$ & $\begin{array}{c}5 \text { arrobas de lana } \\
\text { buena }\end{array}$ & $\begin{array}{l}\text { Pedro Calvo, veci- } \\
\text { no de Laguna de } \\
\text { Cameros }\end{array}$ & - \\
\hline
\end{tabular}

${ }^{18}$ Las adquisiciones de lanas estremeñas en el ámbito soriano por parte de mercaderes riojanos, se constatan por lo menos desde el reinado de los Reyes Católicos (DiAGo Hernando, Máximo: «El comercio de lanas en Soria en época de los Reyes Católicos» en Celtiberia (Soria) 78 (1989) págs. 25-75).

${ }_{19}$ El mismo año de 1535 el mercader Hernando de Bazán había adquirido en Yanguas 4.500 lanas estremeñas por un precio de 263.250 maravedís (A.H.P.L.R.: P.N. Escribanía de Francisco López de Salvatierra. C. 476 (22-IX-1535).

${ }^{20}$ A.H.P.L.R.: P.N. Escribanía de Diego Ibáñez. C. 358 (21-VI-1540).

${ }^{21}$ A.R.Ch.V.: R.R.E. C. 333/40. 


\begin{tabular}{|c|c|c|c|c|}
\hline FECHA & $\begin{array}{l}\text { MERCADERES } \\
\text { COMPRADORES }\end{array}$ & Producto & VENDEDORES & CUANTÍA \\
\hline 1535 (23-VIII) & $\begin{array}{l}\text { Juan de Pedroso y } \\
\text { Andrés Gallego }\end{array}$ & $\begin{array}{c}80 \text { arrobas de } \\
\text { lana buena y } \\
\text { blanca estremeña }\end{array}$ & $\begin{array}{c}\text { Pedro Martínez y } \\
\text { Pedro Salvador, } \\
\text { vecinos de Muro de } \\
\text { Cameros }\end{array}$ & $34.400 \mathrm{mrs}$ \\
\hline 1535 (28-VIII) & $\begin{array}{c}\text { Hernando de } \\
\text { Soria y Diego de } \\
\text { Yanguas }\end{array}$ & $\begin{array}{c}930 \text { arrobas de } \\
\text { lana }\end{array}$ & $\begin{array}{c}\text { Hernán Sáenz, } \\
\text { vecino de Yanguas }\end{array}$ & $409.200 \mathrm{mrs}$. \\
\hline 1535 (7-IX) & $\begin{array}{c}\text { Diego de Ribera } \\
\text { «el viejo» }\end{array}$ & $\begin{array}{c}40 \text { arrobas de } \\
\begin{array}{c}\text { lana buena de la } \\
\text { tierra }\end{array} \\
\end{array}$ & $\begin{array}{c}\text { Pedro Campillo, } \\
\text { vecino de Medrano }\end{array}$ & $12.800 \mathrm{mrs}$. \\
\hline 1535 (7-IX) & Pedro de Moraza & $\begin{array}{c}8 \text { arrobas de lana } \\
\text { buena blanca, } \\
\text { churra }\end{array}$ & \begin{tabular}{|c|} 
Juan Miguel y \\
Pedro Miguel, \\
moradores en el \\
Villar de Laguardia
\end{tabular} & 64 reales \\
\hline 1535 (15-IX) & $\begin{array}{l}\text { Antonio de } \\
\text { Yanguas }\end{array}$ & $\begin{array}{c}400 \text { lanas, } 300 \\
\text { estremeñas y } \\
100 \text { churras } \\
\end{array}$ & $\begin{array}{l}\text { Diego de Matute, } \\
\text { de Lardero }\end{array}$ & $19.300 \mathrm{mrs}$. \\
\hline 1535 (16-IX) & $\begin{array}{l}\text { Antonio de } \\
\text { Yanguas }\end{array}$ & $\begin{array}{c}300 \text { lanas de } \\
\text { carneros, buenas, } \\
\text { blancas, sin roña }\end{array}$ & $\begin{array}{l}\text { Martín López, } \\
\text { carnicero de Autol }\end{array}$ & $9.000 \mathrm{mrs}$. \\
\hline 1535 (16-IX) & $\begin{array}{l}\text { Antonio de } \\
\text { Yanguas }\end{array}$ & $\begin{array}{c}667 \text { lanas, buenas, } \\
\text { blancas, churras, } \\
\text { de las que posee } \\
\text { en Quel }\end{array}$ & $\begin{array}{l}\text { Antón del Rey, } \\
\text { vecino de Quel }\end{array}$ & $17.342 \mathrm{mrs}$. \\
\hline 1535 (16-IX) & $\begin{array}{l}\text { Antonio de } \\
\text { Yanguas }\end{array}$ & $\begin{array}{l}400 \text { lanas chu- } \\
\text { rras de Cameros } \\
\text { y de su ganado } \\
\text { de Quel }\end{array}$ & $\begin{array}{c}\text { Diego Marzo, veci- } \\
\text { no de Quel }\end{array}$ & $10.400 \mathrm{mrs}$. \\
\hline 1535 (21-IX) & $\begin{array}{l}\text { Hernando de } \\
\text { Bazán }\end{array}$ & $\begin{array}{l}298 \text { lanas bue- } \\
\text { nas, blancas, } \\
\text { enteras, sin roña }\end{array}$ & \begin{tabular}{|c|} 
Pedro Valle y Juan \\
López, vecinos de \\
Vadillos y Juan \\
Fernández, vecino \\
de San Llorente \\
\end{tabular} & $13.708 \mathrm{mrs}$. \\
\hline 1535 (22-IX) & $\begin{array}{l}\text { Hernando de } \\
\text { Bazán }\end{array}$ & $\begin{array}{l}190 \text { arrobas de } \\
\text { lana buena es- } \\
\text { tremeña de car- } \\
\text { neros y ovejas }\end{array}$ & $\begin{array}{l}\text { Pedro Ruiz Simón, } \\
\text { Pedro Ruiz de San } \\
\text { Pedro, Fco. Moreno } \\
\text { y Fco. de la Cáma- } \\
\text { ra, vecinos de La- } \\
\text { guna de Cameros }\end{array}$ & $76.000 \mathrm{mrs}$. \\
\hline $1535(2-\mathrm{X})$ & $\begin{array}{c}\text { Hernando de } \\
\text { Bazán y Juan de } \\
\text { Bazán }\end{array}$ & $\begin{array}{c}60 \text { arrobas de } \\
\text { lana buena blan- } \\
\text { ca }\end{array}$ & $\begin{array}{c}\text { Juan García, vecino } \\
\text { de Gallinero }\end{array}$ & $27.300 \mathrm{mrs}$. \\
\hline $1535(2-\mathrm{X})$ & $\begin{array}{c}\text { Hernando de } \\
\text { Bazán y Juan de } \\
\text { Bazán }\end{array}$ & $\begin{array}{l}10 \text { arrobas de } \\
\text { lana buena }\end{array}$ & $\begin{array}{l}\text { Pedro Hernández, } \\
\text { vecino de Almarza } \\
\text { de Cameros }\end{array}$ & $4.500 \mathrm{mrs}$. \\
\hline
\end{tabular}




\begin{tabular}{|c|c|c|c|c|}
\hline FECHA & $\begin{array}{l}\text { MERCADERES } \\
\text { COMPRADORES }\end{array}$ & Producto & VENDEDORES & CUANTÍA \\
\hline $1535(5-X)$ & $\begin{array}{c}\text { Hernando de } \\
\text { Bazán y Juan de } \\
\text { Bazán }\end{array}$ & $\begin{array}{c}20 \text { arrobas de } \\
\text { lana buena }\end{array}$ & $\begin{array}{l}\text { Gómez González, } \\
\text { vecino de Albelda }\end{array}$ & $4.000 \mathrm{mrs}$. \\
\hline $1535(12-\mathrm{X})$ & $\begin{array}{c}\text { Hernando de } \\
\text { Bazán y Juan de } \\
\text { Bazán }\end{array}$ & $\begin{array}{c}7 \text { arrobas de lana } \\
\text { buena }\end{array}$ & $\begin{array}{c}\text { Tomás Sáenz, veci- } \\
\text { no de Gallinero de } \\
\text { Cameros }\end{array}$ & $3.157 \mathrm{mrs}$. \\
\hline 1535 (19-X) & $\begin{array}{c}\text { Francisco de } \\
\text { Navarrete }\end{array}$ & $\begin{array}{c}100 \text { lanas buenas } \\
\text { blancas }\end{array}$ & $\begin{array}{c}\text { Martín Pérez, veci- } \\
\text { no de Luezas }\end{array}$ & $2.700 \mathrm{mrs}$. \\
\hline $1535(19-X)$ & Pedro de Enciso & 1.000 lanas & $\begin{array}{l}\text { Salvador Valles, } \\
\text { vecino de Alfaro }\end{array}$ & $30.000 \mathrm{mrs}$. \\
\hline $1535(26-X)$ & Pedro Sánchez & 1.000 lanas & $\begin{array}{l}\text { Francisco García, } \\
\text { vecino de Soto }\end{array}$ & $55.000 \mathrm{mrs}$. \\
\hline $1535(28-X)$ & $\begin{array}{c}\text { Diego de Ribera } \\
\text { «el viejo» }\end{array}$ & $\begin{array}{c}60 \text { arrobas de } \\
\text { lana buena }\end{array}$ & $\begin{array}{c}\text { Juan Andrés, veci- } \\
\text { no de Sojuela }\end{array}$ & - \\
\hline $1535(4-X)$ & $\begin{array}{c}\text { Hernando de } \\
\text { Bazán y Juan de } \\
\text { Bazán }\end{array}$ & $\begin{array}{l}82 \text { arrobas de } \\
\text { lana buena es- } \\
\text { tremeña }\end{array}$ & $\begin{array}{c}\text { Juan Larios y Die- } \\
\text { go Ochoa, vecinos } \\
\text { de Gallinero de los } \\
\text { Cameros }\end{array}$ & $37.310 \mathrm{mrs}$. \\
\hline $1535(21-X)$ & $\begin{array}{c}\text { Hernando de } \\
\text { Bazán }\end{array}$ & $\begin{array}{c}15 \text { arrobas de } \\
\text { lana buena }\end{array}$ & $\begin{array}{l}\text { Pedro Estebanía, } \\
\text { de Villamediana }\end{array}$ & $3.600 \mathrm{mrs}$ \\
\hline $1535(26-X)$ & $\begin{array}{c}\text { Diego de Ribera } \\
\text { «el viejo» }\end{array}$ & $\begin{array}{l}80 \text { lanas buenas } \\
\text { blancas, churras }\end{array}$ & $\begin{array}{c}\text { Sebastián Ruiz, } \\
\text { morador en Elciego }\end{array}$ & $2.560 \mathrm{mrs}$ \\
\hline 1535 (16-XI) & $\begin{array}{c}\text { Antonio de } \\
\text { Yanguas }\end{array}$ & 100 lanas & $\begin{array}{l}\text { Diego Sánchez, } \\
\text { vecino de Ocón }\end{array}$ & $3.400 \mathrm{mrs}$ \\
\hline 1535 (22-XI) & $\begin{array}{l}\text { Antonio de } \\
\text { Yanguas }\end{array}$ & 400 lanas & $\begin{array}{c}\text { Miguel Pérez, veci- } \\
\text { no de la villa de } \\
\text { Quel }\end{array}$ & $10.400 \mathrm{mrs}$. \\
\hline 1535 (22-XI) & $\begin{array}{c}\text { Antonio de } \\
\text { Yanguas }\end{array}$ & 150 lanas & $\begin{array}{l}\text { Juan Barrio, vecino } \\
\text { de la villa de Ocón }\end{array}$ & $4.200 \mathrm{mrs}$. \\
\hline $1535(25-\mathrm{XI})$ & Pedro de Enciso & 200 lanas & $\begin{array}{c}\text { Juan Alonso, veci- } \\
\text { no de la villa de } \\
\text { Murillo }\end{array}$ & $6.800 \mathrm{mrs}$ \\
\hline 1535 (7-XII) & Pedro Sáenz & 400 lanas & $\begin{array}{c}\text { Juan Gutiérrez «el } \\
\text { viejo», morador en } \\
\text { Aldeanueva y veci- } \\
\text { no de Calahorra }\end{array}$ & $14.000 \mathrm{mrs}$. \\
\hline 1535 (30-XII) & $\begin{array}{c}\text { Diego de Ribera } \\
\text { «el viejo» }\end{array}$ & 50 lanas & $\begin{array}{l}\text { Pedro Estebanía, } \\
\text { de Villamediana }\end{array}$ & $2.000 \mathrm{mrs}$. \\
\hline
\end{tabular}

Fuente: A.H.P.L.R.: P.N. Escribanía de Cristóbal Rodríguez. C. 473.

Si los territorios camero-riojano y soriano conformaban los centros principales de aprovisionamiento de materia prima (lana) por parte de los mercaderes logroñeses, las ferias de Medina del Campo y de Medina de Rioseco, así como 
la villa de Bilbao, se constituyeron en plazas de especial relevancia para la obtención de productos manufacturados: paños y otras mercancías que los mercaderes vendían posteriormente en sus tiendas de la ciudad. En este sentido, la participación de mercaderes logroñeses en las importantes ferias de Medina del Campo está documentada desde fines del siglo XV y a lo largo de las primeras décadas del siglo XVI, acudiendo a las mismas con objeto de comprar mercancías y también para cobrar o pagar determinadas cantidades de dinero que les eran debidas o que debían, pues no en vano estas ferias fueron punto de encuentro de mercaderes y hombres de negocio para la concertación de operaciones mercantiles y financieras. A fines del siglo XV consta la intervención en estas ferias de mercaderes logroñeses como Gonzalo de Salamanca y Juan de $\mathrm{Gauna}^{22}$, y más adelante contamos con diversos testimonios tanto para las ferias de Medina del Campo como para las de Medina de Rioseco.

En 1532, por ejemplo, fueron protagonistas, entre otros, los siguientes mercaderes de Logroño que pasaron por el registro notarial del escribano Cristóbal Rodríguez. En primer lugar, Pedro de Enciso «el viejo», que el 17 de junio dio poder a un vecino de la ciudad para acudir a las ferias de Medina del Campo, a cobrar 850 ducados de oro que le eran debidos por Francisco de Medrano en «virtud» de una cédula de cambio enviada por Hernando de Orozco, estante en Flandes. En segundo lugar, los mercaderes Hernando de Soria, Diego de Yanguas y Antonio de Yanguas, que el 21 de septiembre se obligaron a pagar 2.000 coronas de oro en la feria de Medina de Rioseco a los vecinos de Burgos, Gracián y Hernando de Matanza. En tercer lugar, el ya conocido mercader Diego Rodríguez, que el 10 de diciembre dio poder a su hijo para que pudiera comprar paños y otras mercancías en la feria de Medina del Campo, por un valor de 75.000 maravedís ${ }^{23}$. Y las referencias aumentan todavía más a partir de la década de los años cuarenta siglo XVI, cuando documentamos en las ferias de Medina del Campo a diversos mercaderes riojanos procedentes de Arnedo, Alfaro, Calahorra, Haro, Santo Domingo de la Calzada, Logroño, Nájera, Navarrete, Ezcaray y Torrecilla de Cameros. Entre ellos se encontraban personajes como Francisco de Yanguas, vecino de Calahorra; Antonio de Zaldo, Francisco de Ocio y Martín de Ocio, mercaderes de Santo Domingo de la Calzada; Juan de Enciso, Pedro Moreno, Francisco de Soria y Francisco de Villoslada, hombres de negocio de Logroño; o Álvaro de Salinas, mercader vecino de Nájera ${ }^{24}$.

En cuanto al papel de villa de Bilbao, una fuente de información fundamental sigue siendo también en este caso el registro notarial del escribano Cris-

22 Cantera Montenegro, Enrique: «La adaptación de la sociedad logroñesa a la crisis bajomedieval. Las minorías» en Historia de la ciudad de Logroño..., o.c., págs. 420-421.

${ }^{23}$ A.H.P.L.R.: P.N. Escribanía de Cristóbal Rodríguez. C. 472 (17-VI-1532, 21-IX-1532 y 10-XII-1532).

${ }^{24}$ Rojo Vega, Anastasio: Guía de mercaderes y mercaderías en las ferias de Medina del Campo. Siglo XVI, Valladolid, 2004. 
tóbal Rodríguez, donde los mercaderes logroñeses dejaban testimonio de sus «tratos de mercaduría» en la villa vizcaína. El 17 de julio de 1532, por ejemplo, el mercader logroñés, Diego Rodríguez, dio poder a su hermano, Cristóbal Rodríguez:

"para que por mi y en mi nombre e commo yo mismo podais comprar e compreis en la villa de Bilbao de qualesquier personas e mercaderos que quisieredes e por bien tobieredes ansi vesinos de la dicha villa de Bilbao commo de otras partes e lugares qualesquier de qualesquier mercadurias ansi de pannos como de otras cosas hasta en quantia de noventa mill maravedis» 25 .

Se trataba de unos vínculos comerciales plasmados asimismo en la participación de vecinos de Bilbao en el abasto del mercado local de núcleos urbanos riojanos como Haro o Santo Domingo de la Calzada ${ }^{26}$; pero sobre todo en la ingente actividad mercantil desplegada en la villa vizcaína desde la primera mitad del siglo XVI por los mercaderes logroñeses, que junto a mercaderes de otras localidades riojanas, actuaron en calidad de mercaderes principales y clientes de algunos de los más destacados cargadores, factores y encomenderos que actuaban en la pujante villa de Bilbao, uno de los principales puertos de salida de mercancías del Reino a los mercados europeos desde la Baja Edad Media ${ }^{27}$.

Así se puede constatar a partir de un reciente trabajo realizado por el profesor Alberto Angulo Morales, quien ha podido documentar a diferentes mercaderes riojanos que negociaban por Bilbao en 1547 y años posteriores, entre los que encontramos a algunos ya conocidos. Por lo que respecta a Logroño se señalaba en 1547 a Rodrigo de Soria, Diego de Yanguas, Antonio de Yanguas, Alonso Ruiz, Pedro de Enciso, Luis de Sesma, Juan de Bazán, Andrés Gallego y Juan Fernández de Navarrete, entre otros mercaderes clientes del mercader y encomendero bilbaíno Martín de Bertendona. Y la información aumenta a partir de mediados del siglo XVI, cuando documentamos negociando por Bilbao a diversos mercaderes de Ezcaray, Nájera, Navarrete, Torrecilla de Cameros o Santo Domingo de la Calzada, ciudad esta última representada, entre otros, por varios miembros de la familia Ocio, tales como Francisco de Ocio, Martín de Ocio, Diego de Ocio, o Pedro de Ocio Vallejo ${ }^{28}$.

Desde finales del siglo XV podemos confirmar, por lo demás, que diferentes miembros de estas familias de mercaderes y algunos otros participaban en

25 A.H.P.L.R.: P.N. Escribanía de Cristóbal rodríguez.c. 472 (17-VII-1532).

${ }^{26}$ GOICOLEA JUlián, Fco. Javier: «Mundo urbano..., o.c., págs. 275-276.

27 INCLÁN GIL, Eduardo: «El dinero de la mar: el comercio de la costa vasca con Europa en los siglos XIV al XVI» en Bilbao, Vitoria y San Sebastián: Espacios para mercaderes, clérigos y gobernantes en el Medievo y la Modernidad, Bilbao, 2005, págs. 17-78.

28 ANGUlo MORALES, Alberto: «En poco tiempo vienen ricos e hazen a sus amos pobres. De factores o encomenderos a protagonistas directos del gran comercio internacional (siglos XV-XVII)» en Bilbao..., o.c., págs. 79-115. 
los circuitos comerciales internacionales, centrándose su interés mercantil en la venta de la lana adquirida en Cameros o en Soria, así como en la adquisición de diversos productos como paños y materiales para el acabado de los mismos. De esta manera se puede deducir, por lo menos, de la lectura de algunos documentos desde finales del siglo XV. En 1488, por ejemplo, el mercader logroñés Rodrigo de Ruego, había comprado 140 sacas de lana al contador del conde de Aguilar y a un pariente suyo, vecinos de Yanguas, con la intención de trasladarlas para su venta a Bretaña y Flandes ${ }^{29}$. Varios años antes, hacia 1484, los mercaderes calceatenses Juan Sánchez de Ocio y Sebastián de Ocio, también vinculados al comercio de la lana y de los paños, habían acudido a comerciar a la ciudad francesa de Toulouse, donde adquirieron, entre otras cosas, pastel ${ }^{30}$; mientras en 1490 el mercader de Haro, Mantín Fernández de Izaguirre, llegó a un acuerdo con el concejo de la villa para traer de la ciudad italiana de Florencia «pannos de damasco» por valor de 76.321 maravedís $^{31}$.

$\mathrm{Y}$ los datos en este sentido aumentan en la primera mitad del siglo XVI, cuando algunos documentos, además de poner de manifiesto los vínculos que tenían los mercaderes logroñeses con los burgaleses, confirman asimismo los intereses comerciales que unos y otros poseían en ciudades de Flandes, especialmente en Brujas, uno de los centros europeos del negocio lanero por excelencia $^{32}$. El 21 de septiembre de 1532 hay constancia de que los mercaderes logroñeses Hernando de Soria, Diego de Yanguas y Antonio de Yanguas, se comprometieron a hacer efectivo en la ciudad de Brujas un pago de 2.000 coronas de oro a los vecinos de Burgos, Gracián y Hernando de Matanza ${ }^{33}$. Precisamente en la ciudad de Brujas residía por esas fechas Rodrigo de Soria, hermano de Diego y Antonio, tal y como pone de manifiesto un documento fechado a 30 de junio de 1532, cuando Hernando de Soria, junto a Diego de Yaguas, Antonio de Yanguas y Bartolomé de Poza, avalaron a Rodrigo de Soria, residente en Brujas, en el desempeño de sus funciones de factor del mercader de Burgos, Gómez de Nájera ${ }^{34}$. Lo cierto es que la presencia temporal de vecinos riojanos en ciudades de Flandes en las primeras décadas del siglo XVI no debió ser excepcional, pues tenemos noticias asimismo de que otros miembros de familias de mercaderes también estuvieron presentes en ese territorio. Tal fue el caso del vecino y mercader de Santo Domingo de la Calzada, Lope de Ocio, quien en la primera mitad del siglo XVI estuvo residiendo en Flandes por espacio de varios años, regresando posteriormente a la ciudad calceatense

29 A.G.S.: R.G.S., fol. 89 (29-IV-1488).

30 Moya Valgañón, José Gabriel: Documentos para la Historia del Arte del Archivo Catedral de Santo Domingo de la Calzada, 1443-1563, Logroño, 1986, doc. nº 63, pág. 62.

31 A.M.H.: L.A. 1490, sesión del 11 de noviembre.

32 Casado Alonso, Hilario: El triunfo de Mercurio..., o.c., págs. 81-98.

33 A.H.P.L.R.: P.N. Escribanía de Cristóbal Rodríguez. C. 472 (21-X-1532) y documento III del Apéndice.

${ }^{34}$ Ibídem. (30-VI-1532) y documento I del Apéndice. 
para casarse ${ }^{35}$. Y lo mismo se puede decir del vecino de Logroño, Pedro Moreno de León, quien en su testamento de 1553 se acordaba de los hijos no legítimos que había tenido en Flandes, a quienes legaba cincuenta ducados ${ }^{36}$.

No cabe duda, por fin, de que las empresas comerciales más ambiciosas y de más amplio radio en que se veían inmersos los mercaderes riojanos, requerían unas inversiones cada vez mayores de capital, lo que dio lugar a la formación de compañías de comerciantes, cuyo funcionamiento se puede observar en Logroño en la primera mitad del siglo XVI. En efecto, en su testamento escriturado junto a su esposa en $1532^{37}$, Hernando de Soria dejaba constancia de que había tenido «trato de mercaduría» con muchas personas, señalando asimismo que había formado compañías con otros mercaderes de Logroño para la realización de diversos negocios mercantiles. Entre los mercaderes asociados se encontraban su hermano Rodrigo de Soria, Diego de Yanguas y Rodrigo de Yanguas, además de otros destacados miembros de la élite de hombres de negocio logroñeses, tales como el doctor Diego de Villoslada, Juan de Gauna, Alonso de San Pedro o Juan de Navarrete. De acuerdo con la última voluntad de Hernando de Soria, debían pagarse y finiquitarse las cuantías de dinero por él debidas en sus «tratos de mercaderías y compañías» y otros negocios, cuyos resultados estaban asentados en su libro de cuentas. Sobre todo, Hernando de Soria tenía una especial preocupación por los negocios realizados en las compañías que había mantenido con otros mercaderes de la ciudad, especialmente con su hermano, Rodrigo de Soria, y con Diego de Yanguas.

\section{OTRAS FUENTES DE INGRESO.}

El comercio constituyó, en definitiva, la principal fuente de enriquecimiento de los hombres de negocio riojanos, aunque no fue la única actividad económica desplegada que les proporcionaba beneficios. En efecto, como ocurrió en otras ciudades y villas de la Corona de Castilla ${ }^{38}$, los negocios mercantiles fueron complementados por los mercaderes riojanos con otro tipo de actividades como la recaudación de rentas, actividad que documentamos ya a mediados del siglo XV, cuando Enrique IV otorgó al vecino de Nájera, Juan de Salinas, la «receptoría» de la Bula de la Santa Cruzada en el señorío de Vizcaya y en la provincia de Guipúzcoa, según consta en carta fechada el 30 de mayo de

35 A.R.Ch.V.: P.C. Escribanía de Moreno (F). C. 496-2, leg. 91.

36 SÁINZ RIPA, Eliseo: Santa María de la Redonda. De iglesia parroquial a iglesia concatedral. Siglos XII-XX, Logroño, 1992, pág. 65.

37 A.H.P.L.R.: P.N. Escribanía de Cristóbal Rodríguez. C. 472 (1-VI-1532) y GoicoleA Julián, Fco. Javier: «La élite ciudadana de Logroño en el tránsito de la Edad Media a la Moderna: Las familias Soria y Yanguas» en Berceo (Logroño) 150 (2006) págs. 115-141.

38 García FernándeZ, Ernesto: Gobernar la ciudad en la Edad Media: Oligarquías y elites urbanas en el País Vasco, Vitoria, 2004, págs. 281-363. 
145739. Ahora bien, es algunas décadas después cuando podemos comprobar de forma más clara la intervención de los hombres de negocio riojanos en la gestión de rentas reales, sobre todo por lo que atañe al arrendamiento de las alcabalas, impuesto real que gravaba un tanto por ciento de las compra-ventas y que a fines de la Edad Media se convirtió en el tributo indirecto más importante que ingresaba la hacienda regia castellana ${ }^{40}$.

La documentación procedente de las secciones de Escribanía Mayor de Rentas, Contaduría Mayor de Cuentas y Expedientes de Hacienda del Archivo General de Simancas, nos permite distinguir a varios hombres de negocio riojanos que tomaron en renta las alcabalas de las merindades de Rioja, Nájera y Logroño en los años finales del siglo XV e inicios del XVI ${ }^{41}$. Se trata de vecinos de Santo Domingo de la Calzada, como Fernando Alonso de Valencia, que tomó en renta las alcabalas y tercias de las merindades de Rioja y Logroño en 1479 y 1480, comprometiéndose a pagar junto a su socio una cuantía de 150.000 maravedís en cada uno de los años. Y junto a él, documentamos asimismo a varios miembros de la ya mencionada familia calceatense de los Ocio, concretamente a Juan Sánchez de Ocio, que fue arrendador mayor de las alcabalas de la merindad de Allende Ebro en 1493, y también a Sebastián, Pedro y Cristóbal de Ocio, que tomaron en renta las alcabalas de la merindad de Rioja en 1506, 1507, 1510, 1511 y en varios años más de la primera mitad de la centuria del quinientos ${ }^{42}$. Por lo que respecta a Sebastián y a Cristóbal de Ocio sabemos, además, que se interesaron por la explotación de las rentas de diferentes salinas, como las alavesas de Buradón, tomadas en arriendo por Sebastián de Ocio en los primeros años del siglo XVI ${ }^{43}$, o las burgalesas de Poza de la Sal, tomadas en renta por Cristóbal de Ocio y su socio Martín de Cuzcurrita por un período de cuatro años que comenzó en $1520^{44}$.

Entre los arrendadores mayores de alcabalas nos encontramos asimismo con mercaderes de Arnedo, como Diego de Baeza, que en 1484 era arrendador de las alcabalas y tercias de la merindad de Logroño junto al judío Isaque Cohen; con miembros de conocidas familias de hombres de negocio de la ciudad de Nájera, como Diego de Salinas, hijo del ya citado Juan de Salinas, que fue arrendador de las alcabalas de la merindad de Logroño en 1483; y con mercaderes de Logroño. Entre ellos distinguimos a Alonso Martínez Moreno y a su hijo Fernando Moreno, que en 1480 y junto a Juan de Peralta tomaron en renta las alcabalas y tercias de la ciudad de Logroño y su tierra por una cuantía de

39 A.G.S.: E.M.R., leg. 8-2.

40 Ladero Quesada, Miguel Ángel: La hacienda real de Castilla en el siglo XV, Tenerife, 1973.

41 A.G.S.: C.M.C., $1^{\mathrm{a}}$ época, legs. 8, 56, 73; E.M.R., legs. 23, 26, 37, 44, 45, 695, 696 y E.H., leg. 5 .

42 El dato referente a la merindad de Allende Ebro procede de GARCía FERnÁNDEZ, Ernesto: Gobernar la ciudad..., o.c., pág. 179.

43 A.G.S.: E.M.R., leg. 684.

44 A.R.Ch.V.: P.C. Escribanía de Taboada (F). C. 1074-4, leg. 193. 
317.000 maravedís, y también a Gonzalo Alonso de Navarrete, Pedro de Yanguas y Rodrigo de Yanguas, quienes fueron arrendadores mayores de las alcabalas de las merindades de Rioja y Logroño entre 1498 y 1500.

Tampoco fue desdeñable la participación de estos ciudadanos en el arrendamiento de alcabalas al por menor, tal y como se constata especialmente bien en la ciudad de Santo Domingo de la Calzada en los años finales del siglo XV, a partir de la documentación fiscal conservada que ya hemos citado ${ }^{45}$. En efecto, sabemos que en esta ciudad fueron arrendadores menores de alcabalas ciudadanos como Pedro Fernández de Valencia, Diego de Samaniego, Pedro de Samaniego, Martín de Valderrama, Pedro López Lacayo, Sancho Lacayo y Diego López Mancebo. El papel de estos vecinos poderosos de Santo Domingo de la Calzada no se circunscribió, por lo demás, únicamente a la toma en arriendo de las alcabalas de la ciudad, de manera que en algunos casos hemos podido comprobar su participación en el arrendamiento de las alcabalas de algunas localidades de las merindades de Rioja y Nájera. Pedro de Samaniego arrendó en 1495 las alcabalas de Pazuengos por 11.200 maravedís, Martín de Valderrama las de Cirueña por 16.846 maravedís, Sancho Lacayo las de Badarán por 26.000 maravedís, y Juan Sánchez de Ocio las de Villalobar, Cihuri y Cordovín por $7.000,9.600$ y 7.000 maravedís respectivamente.

En cuanto a la villa de Haro, entre los arrendadores de alcabalas al por menor, se puede destacar al mercader Martín Sánchez de Tricio, que como ya sabemos participó en el abasto de la carnicería y tiendas de Haro a fines del siglo $\mathrm{XV}$, y que en 1470 tomó en renta la alcabala de la carnicería cristiana de la villa ${ }^{46}$. Para el caso de este núcleo urbano de la merindad de Rioja contamos además con abundante información sobre la participación de mercaderes en la toma en arriendo de otras rentas, como las eclesiásticas y concejiles. Con relación a las primeras, sabemos que en los años finales del siglo XV el mercader Martín Fernández de Izaguirre había sido arrendador de la renta de la Primicia, por la que había pujado en 1490 con 80.000 maravedís $^{47}$. Y la información es más profusa para las rentas concejiles, de manera que la conservación de Libros de cuentas del siglo XV nos ha permitido distinguir entre los renteros de las sustanciosas rentas concejiles del pontazgo, sisa del vino o carnicería, a mercaderes como Fernando de Santa María, Pedro de Ollauri, Juan Martínez de Briñas y Juan García de Briñas ${ }^{48}$. Por fin, contamos con datos similares, aunque más reducidos, para Nájera y Navarrete. En Nájera documentamos a Juan Manuel, Juan de Yanguas, Fernando y Juan Díaz, y al propio alcaide Juan de Salinas tomando en arriendo las rentas del peaje del puente, correduría, haber

\footnotetext{
45 Remito a nota 41.

${ }^{46}$ Goicolea Julián, Fco. Javier: Haro: Una villa riojana..., o.c., págs. 217-223.

47 A.M.H.: L.A. 1490, sesión del 7 de noviembre y Libros de la Primicia de la iglesia de Santo Tomás de Haro, 1435-1502.

48 Goicolea Julián, Fco. Javier: Haro: Una villa riojana..., o.c., págs. 209-214.
} 
del peso, sisa del vino y trujal en la segunda mitad del siglo $\mathrm{XV}^{49}$; mientras en Navarrete las informaciones son posteriores, de la segunda mitad del siglo XVI. Concretamente consta que en 1542, Diego Martínez del Pozo, hijo del mercader acomodado, Juan del Pozo, tomó en renta el sustancioso tributo municipal de la «cántara y sacar de los cueros» por 29.000 maravedís ${ }^{50}$.

Como se puede comprobar de los datos expuestos, y al igual que ocurrió en el caso de los negocios mercantiles, también fue frecuente la asociación de hombres de negocio en el arrendamiento de rentas. En este sentido, no cabe duda de que los vínculos familiares también funcionaban en este tipo de negocios, tal y como hemos podido comprobar en los casos de los Moreno y Yanguas de Logroño o en relación con los Ocio de Santo Domingo de la Calzada; si bien, las asociaciones sobrepasaban con frecuencia el marco familiar. Por ejemplo, en 1480, la alcabala del vino de la ciudad de Santo Domingo de la Calzada, valorada en 76.876,5 maravedís, fue tomada en renta por Pedro Fernández de Valencia, Juan de Ibarra y Alonso de Santurde; y el mismo número de socios participaron ese mismo año en el arrendamiento de la alcabala de los paños. Concretamente fueron Fernando Alonso de Valencia, el escribano Pedro Sánchez y Diego de Samaniego quienes tomaron en renta la referida alcabala por un precio de 52.412 maravedís ${ }^{51}$. Y las asociaciones de mercaderes también funcionaron en el arrendamiento de rentas eclesiásticas, tal y como pone de manifiesto la sociedad convenida entre los mercaderes logroñeses Fernando de Soria y Alonso de San Pedro para tomar en arriendo la notaría pública de la Audiencia del obispado de Calahorra y la Calzada en $1517^{52}$.

Otra fuente de ingreso de los hombres de negocio riojanos estuvo representada por la percepción de juros situados en las rentas reales, tal y como se constata asimismo a partir de la documentación fiscal contenida en las secciones del Archivo General de Simancas ${ }^{53}$. Se trata de un volumen de documentos sobre las referidas merindades de Rioja, Nájera y Logroño, que pone de manifiesto que los principales beneficiarios de los juros fueron sobre todo diversos miembros de la nobleza señorial e instituciones eclesiásticas, pero también diferentes familias de mercaderes y hombres de negocio riojanos, quienes obtuvieron tales prebendas gracias a la concesión de mercedes regias y mediante la inversión en la deuda pública de la hacienda regia desde la época de los Reyes Católicos (juros «al quitar» $)^{54}$. En el primero de los supuestos, hay constancia de que perci-

49 A.M.N.: L.C. $1455-1456$ y 1476-1477.

50 A.R.Ch.V.: P.C. Escribanía de Lapuerta (F). C. 2559-1 y GoicoleA Julián, Fco. Javier: «Navarrete a finales de la Edad Media: Gobierno y sociedad en una villa riojana de señorío» en Berceo (Logroño) 136 (1999) págs. 59-86.

51 A.G.S.: E.H., leg. 5.

52 A.R.Ch.V.: P.C. Escribanía de Masas (O). C. 948/4, leg. 296.

53 A.G.S.: C.M.C., legs. 8, 65, 73, E.M.R., leg. 44 y E.H., leg. 5.

54 Toboso SÁnchez, P.: La deuda pública castellana durante el Antiguo Régimen (Juros) y su liquidación en el siglo XIX, Madrid, 1987. 
bieron juros determinados miembros de la familia Ocio de Santo Domingo de la Calzada a lo largo del siglo XV; mientras en Nájera el alcaide Juan de Salinas fue recompensado con 16.666 maravedís y 4 cornados "por privillegio de juro e de heredad, confirmado por los muy altos e muy poderosos reyes e sennores don Fernando e donna Isabel», debiendo percibirse tal cuantía de dinero en las alcabalas de la ciudad de Logroño. Se trataba en ambos casos de juros de «heredad», y que por lo tanto fueron transmitidos de padres a hijos a fines de la Edad Media. Efectivamente, en relación con los Ocio sabemos que el juro de 2.000 maravedís concedido por Juan II a Diego López de Ocio en 1429, fue transmitido a su hijo Lope Sánchez de Ocio y posteriormente a su nieto, Diego López de Ocio; mientras en el caso de Juan de Salinas, por su testamento redactado en 1479, consta que fueron sus hijos quienes heredaron tal privilegio de juro de «heredad» ${ }^{55}$.

Ahora bien, es a partir de las primeras décadas del siglo XVI cuando se advierte en ciudades como Calahorra y sobre todo Logroño, una participación mucho más activa de hombres de negocio en la percepción de juros «al quitar». De esta manera se puede comprobar en el caso del doctor Juan Martínez de Yanguas, vecino de Calahorra, que percibía 50.000 maravedís anuales situados principalmente en las alcabalas de la ciudad calagurritana y su tierra; o en los casos de Pedro Moreno de León, Pedro Hernández de Navarrete, Rodrigo de Soria, Pedro de Soria y María de Enciso, hija del contador real Juan de Enciso y mujer de Miguel Moreno de León. Todos ellos eran vecinos de Logroño que hacia mediados del siglo XVI percibían juros «al quitar» por importes que oscilaban entre los 14.000 y más de 100.000 maravedís situados en las alcabalas de Logroño y su merindad, que incluía la urbe de Calahorra, y en villas sorianas como Ágreda, donde consta que Miguel Moreno de León ingresaba todos los años una cuantía de 150.000 maravedís situados en sus alcabalas, tal y como queda confirmado en un documento de $1535^{56}$.

TABLA 4. ALGUNOS CIUDADANOS RIOJANOS PERCEPTORES DE JUROS «AL QUITAR» A MEDIADOS DEL SIGLO XVI

\begin{tabular}{|l|l|}
\hline TITULARES & CANTIDAD ASIGNADA Y LUGAR \\
\hline $\begin{array}{l}\text { Juan Martínez de Yanguas, veci- } \\
\text { no de Calahorra }\end{array}$ & $\begin{array}{l}50.000 \mathrm{mrs} \text {. en las alcabalas de Logroño y su } \\
\text { merindad, principalmente en varios miembros de } \\
\text { renta de la ciudad de Calahorra y su tierra }\end{array}$
\end{tabular}

55 A.H.P.A.: Archivo Familiar Ocio-Salazar, 21815 y EnRíQuez FernándeZ, Javier y otros: Colección Documental de los monasterios de Santo Domingo de Lequeitio (1289-1520) y Santa Ana de Elorrio (1480-1520), San Sebastián, 1993, doc. nº 50.

56 A.G.S.: C.M.C., $1^{\mathrm{a}}$ época, leg. 73 y A.H.P.L.R.: P.N. Escribanía de Cristóbal Rodríguez. C. $473(23-$ IX-1535). 


\begin{tabular}{|l|l|}
\hline TITULARES & CANTIDAD ASIGNADA Y LUGAR \\
\hline $\begin{array}{l}\text { Francisco de Cazalla, vecino de } \\
\text { Logroño }\end{array}$ & $\begin{array}{l}30.000 \mathrm{mrs} \text {. en las alcabalas de Logroño y su } \\
\text { merindad, principalmente en varios miembros de } \\
\text { renta de la ciudad de Logroño }\end{array}$ \\
\hline $\begin{array}{l}\text { Fernando Vázquez, vecino de } \\
\text { Logroño }\end{array}$ & $\begin{array}{l}41.000 \mathrm{mrs} \text {. en las alcabalas de Logroño y su } \\
\text { merindad, principalmente en varios miembros de } \\
\text { renta de la ciudad de Logroño }\end{array}$ \\
\hline $\begin{array}{l}\text { Alvar Pérez, licenciado, vecino de } \\
\text { Logroño }\end{array}$ & $\begin{array}{l}21.000 \mathrm{mrs} \text {. en las alcabalas de Logroño y su } \\
\text { merindad, principalmente en varios miembros de } \\
\text { renta de la ciudad de Logroño }\end{array}$ \\
\hline $\begin{array}{l}\text { Pedro Moreno de León, vecino de } \\
\text { Logroño }\end{array}$ & $\begin{array}{l}102.000 \mathrm{mrs.} \mathrm{en} \mathrm{las} \mathrm{alcabalas} \mathrm{de} \mathrm{Logroño} \mathrm{y} \mathrm{su} \\
\text { merindad }\end{array}$ \\
\hline $\begin{array}{l}\text { Miguel Moreno de León, vecino } \\
\text { de Logroño }\end{array}$ & $150.000 \mathrm{mrs.} \mathrm{en} \mathrm{las} \mathrm{alcabalas} \mathrm{de} \mathrm{Ágreda.}$ \\
\hline $\begin{array}{l}\text { Pedro Hernández de Navarrete, } \\
\text { vecino de Logroño }\end{array}$ & $\begin{array}{l}15.000 \mathrm{mrs.} \mathrm{en} \mathrm{las} \mathrm{alcabalas} \mathrm{de} \mathrm{Logroño} \mathrm{y} \mathrm{su} \\
\text { merindad, principalmente en las rentas de Arne- } \\
\text { dillo }\end{array}$ \\
\hline $\begin{array}{l}\text { Rodrigo de Soria, vecino de Lo- } \\
\text { groño }\end{array}$ & $\begin{array}{l}100.000 \mathrm{mrs} \text {. en las alcabalas de Logroño y su } \\
\text { merindad, principalmente en varios miembros de } \\
\text { renta de la ciudad de Calahorra y su tierra }\end{array}$ \\
\hline $\begin{array}{l}\text { María de Enciso, vecina de Lo- } \\
\text { groño }\end{array}$ & $\begin{array}{l}50.000 \mathrm{mrs.} \mathrm{en} \mathrm{las} \mathrm{alcabalas} \mathrm{de} \mathrm{Logroño} \mathrm{y} \mathrm{su} \\
\text { merindad, principalmente en varios miembros de } \\
\text { renta de la ciudad de Logroño }\end{array}$ \\
\hline $\begin{array}{l}\text { Pedro de Soria, regidor, vecino } \\
\text { de Logroño }\end{array}$ & $\begin{array}{l}50.000 \mathrm{mrs.} \mathrm{en} \mathrm{las} \mathrm{alcabalas} \mathrm{de} \mathrm{Logroño} \mathrm{y} \mathrm{su} \\
\text { merindad }\end{array}$ \\
\hline $\begin{array}{l}\text { Juan Fernández de Ventosa, } \\
\text { vecino de Logroño }\end{array}$ & $\begin{array}{l}50.000 \mathrm{mrs.} \mathrm{en} \mathrm{las} \mathrm{alcabalas} \mathrm{de} \mathrm{Logroño} \mathrm{y} \mathrm{su} \\
\text { merindad }\end{array}$ \\
\hline $\begin{array}{l}\text { Rodrigo de Soria, vecino de Lo- } \\
\text { groño }\end{array}$ & $\begin{array}{l}14.000 \mathrm{mrs.} \mathrm{en} \mathrm{las} \mathrm{alcabalas} \mathrm{de} \mathrm{Logroño} \mathrm{y} \mathrm{su} \\
\text { merindad }\end{array}$ \\
\hline
\end{tabular}

Fuente: A.G.S.: C.M.C., $1^{\text {a }}$ época, leg. 73

Junto al arrendamiento de rentas y la percepción de juros, los mercaderes riojanos también se dedicaron al préstamo, actividad que, al menos, sabemos que realizaron mercaderes logroñeses en las primeras décadas del siglo XVI, si nos atenemos a los datos expuestos en la Tabla 5. En efecto, se trata de préstamos formalizados entre los meses de julio y octubre del año 1535, casi todos ellos en metálico, y que en algunos casos suponían importantes cantidades de dinero, como los 140.000 maravedís prestados por el licenciado Juan Jiménez de la Torre a Francisco de Navarrete, o los casi 300.000 maravedís prestados por la viuda del poderoso mercader, Rodrigo de Sesma, a sus convecinos Diego de Yanguas y Antonio Ruiz. En este sentido, los beneficiados con los préstamos 
eran en su mayoría vecinos de la urbe logroñesa, aunque también había personas procedentes de villas riojanas como Alfaro o navarras como Los Arcos. Cabe señalar también entre los beneficiarios a uno de los hijos del señor de Agoncillo, que debía devolver los 15.000 maravedís que le habían sido prestados cumplidos quince días después de su boda, o a Remón de Esparza, hombre de armas de la capitanía de don Diego de Osorio, que había solicitado un préstamo de 8.800 maravedís para pagar las nóminas de la gente de la capitanía. En cuanto a la identidad de los prestamistas, ya hemos hablado de algunos de ellos en su faceta de mercaderes de paños. Son los casos de Pedro Sánchez, Andrés Gallego o Bernardino de San Pedro, quien consta igualmente que concedió un préstamo en especie (12 fanegas de trigo) a dos vecinos de Logroño, algo que suponemos que fue más habitual de lo que la documentación consultada pone de manifiesto ${ }^{57}$. Por lo demás, los plazos de devolución podían variar, y en algunos casos se especificaba asimismo el lugar de restitución de la cantidad acordada, ocupando un lugar destacado también en esta materia las ferias de Medina del Campo. En caso de no devolución, y según los contratos establecidos, además de las multas que conllevaban muchas veces el embargo de bienes, los deudores tenían que pagar asimismo el doble del valor del préstamo, lo que debió convertir a estas obligaciones, junto a las derivadas de las propias ventas de paños y otras mercancías que llevaban la misma penalización, en una de las fórmulas utilizadas por los mercaderes para acceder a propiedades agrarias y urbanas a costa del endeudamiento de sus convecinos menos pudientes.

TABLA 5. PRÉSTAMOS EFECTUADOS POR HOMBRES DE NEGOCIO DE LOGROÑO EN 1535

\begin{tabular}{|l|c|c|c|c|}
\hline Asiento & PRESTAMista & BenEFICIARIOS & CUANTía & $\begin{array}{c}\text { FECHA DE } \\
\text { DEVOLUCIÓN }\end{array}$ \\
\hline 1535 (10-VII) & $\begin{array}{c}\text { Diego Díaz } \\
\text { Navarro }\end{array}$ & $\begin{array}{c}\text { Diego Sáenz y An- } \\
\text { tonio de Carasa, } \\
\text { vecinos de Logroño }\end{array}$ & $56.250 \mathrm{mrs}$. & $\begin{array}{c}\text { Primer día del } \\
\text { mes de agosto } \\
\text { de } 1535\end{array}$ \\
\hline 1535 (19-VIII) & $\begin{array}{c}\text { Juan Jiménez } \\
\text { de la Torre, } \\
\text { licenciado }\end{array}$ & Fco. de Navarrete & $140.000 \mathrm{mrs}$. & Plazo de 2 años \\
\hline 1535 (21-VIII) & Fco. López & $\begin{array}{c}\text { Pedro de Porres, } \\
\text { hijo mayorazgo del } \\
\text { señor de Agoncillo }\end{array}$ & $15.000 \mathrm{mrs}$. & $\begin{array}{c}15 \text { días después } \\
\text { de su boda }\end{array}$ \\
\hline
\end{tabular}

57 Hay constancia de que el propio Bernardino de San Pedro efectuó varias ventas de trigo a vecinos de Logroño el mismo año de 1535 (ver Tabla 2). 


\begin{tabular}{|c|c|c|c|c|}
\hline ASIENTO & PRESTAMISTA & BENEFICIARIOS & CUANTÍA & $\begin{array}{c}\text { FECHA DE } \\
\text { DEVOLUCIÓN }\end{array}$ \\
\hline 1535 (22-VIII) & Fco. López & $\begin{array}{l}\text { Remón de Esparza, } \\
\text { hombre de armas } \\
\text { de la capitanía de } \\
\text { don Diego Osorio }\end{array}$ & $\begin{array}{l}8.800 \mathrm{mrs} \\
\text { para pagar las } \\
\text { nóminas de la } \\
\text { gente de la } \\
\text { capitanía }\end{array}$ & $\begin{array}{c}\text { En las tres pri- } \\
\text { meras pagas }\end{array}$ \\
\hline 1535 (23-VIII) & $\begin{array}{c}\text { Diego Díaz } \\
\text { Navarro }\end{array}$ & $\begin{array}{l}\text { Juan de Medrano, } \\
\text { licenciado de la } \\
\text { villa de Los Arcos }\end{array}$ & $75.000 \mathrm{mrs}$. & $\begin{array}{c}\text { Feria de octu- } \\
\text { bre de Medina } \\
\text { del campo de } \\
1535\end{array}$ \\
\hline 1535 (15-IX) & $\begin{array}{l}\text { Bernardino de } \\
\text { San Pedro }\end{array}$ & $\begin{array}{c}\text { Antonio de San } \\
\text { Pedro, su hermano }\end{array}$ & $45.000 \mathrm{mrs}$ & $\begin{array}{c}\text { Cuando se los } \\
\text { demande su } \\
\text { hermano } \\
\end{array}$ \\
\hline 1535 (18-IX) & $\begin{array}{c}\text { Elvira Ruiz, } \\
\text { viuda de Ro- } \\
\text { drigo de Sesma } \\
\end{array}$ & $\begin{array}{l}\text { Diego de Yanguas } \\
\text { y Antonio Ruiz, } \\
\text { vecinos de Logroño }\end{array}$ & 288.427 mrs. & $\begin{array}{c}\text { Feria de mayo } \\
\text { de Medina del } \\
\text { Campo de } 1536 \\
\end{array}$ \\
\hline $1535(20-X)$ & Pedro Sánchez & $\begin{array}{l}\text { Martín Guerrero, } \\
\text { vecino de Alfaro }\end{array}$ & $10.661 \mathrm{mrs}$. & $\begin{array}{l}\text { Mediados del } \\
\text { mes de mayo } \\
\text { de } 1536 \\
\end{array}$ \\
\hline $1535(20-\mathrm{X})$ & $\begin{array}{l}\text { Andrés } \\
\text { Gallego }\end{array}$ & $\begin{array}{c}\text { Juan de Viana, } \\
\text { tundidor de Lo- } \\
\text { groño }\end{array}$ & $12.000 \mathrm{mrs}$. & $\begin{array}{c}\text { En el plazo de } \\
1 \text { año }\end{array}$ \\
\hline $1535(29-X)$ & $\begin{array}{l}\text { Bernardino de } \\
\text { San Pedro }\end{array}$ & $\begin{array}{l}\text { Juan Trigo y Die- } \\
\text { go Salvador, veci- } \\
\text { nos de Logroño }\end{array}$ & $\begin{array}{l}12 \text { fanegas } \\
\text { de trigo }\end{array}$ & $\begin{array}{c}\text { Día y fiesta de } \\
\text { nuestra señora } \\
\text { de agosto de } \\
1536\end{array}$ \\
\hline
\end{tabular}

FuENTE: A.H.P.L.R.: P.N. Escribanía de Cristóbal Rodríguez. C. 473.

Debemos de tener en cuenta asimismo otras fuentes de ingreso, como aquellas derivadas del desempeño de cargos en las administraciones real, señorial y concejil, que no venían determinadas tanto por los salarios obtenidos como por las prebendas que se podían obtener de su vinculación al poder. De esta manera, y como ya ha quedado reflejado en otros estudios, los mercaderes y hombres de negocio riojanos siguieron teniendo un peso específico muy importante en los regimientos municipales de finales de la Edad Media e inicios de la Moderna, que culminaron con la compra de regidurías en las ciudades de realengo a mediados del siglo $\mathrm{XVI}^{58}$. No cabe duda de que desde estos puestos de poder orientaron en determinados momentos en su favor la política económi-

58 Goicolea Julián, Fco. Javier: El gobierno urbano en La Rioja..., o.c., págs. 27-44 y 69-73. 
ca municipal, en ocasiones incluso cometiendo irregularidades ${ }^{59}$, a la vez que obtenían beneficios de sus vinculaciones con los poderes real y señorial. En efecto, sabemos que el alcaide de Nájera Juan de Salinas había sido recompensado por Enrique IV en 1465 con las rentas del portazgo y martiniega que se recaudaban en esa ciudad; mientras en Haro, Gómez Fernández de Ribamartín, secretario de señor de la villa, Pedro Fernández de Velasco, fue recompensado en 1467 con la renta de la escribanía de sacas de $\mathrm{Haro}^{60}$. Y tampoco podían faltar los vínculos con otra de las instituciones de mayor poder, la Iglesia, desempeñando algunos miembros de los linajes de mercaderes, cargos eclesiásticos, tal y como se puede comprobar en el caso del doctor logroñés, Pedro Jiménez de Enciso, quien ejerció como protonotario apostólico, arcediano y canónigo de la iglesia de Santa María de la Redonda en los años finales del siglo XV, acumulando un importante patrimonio de bienes raíces en el término jurisdiccional de Logroño y en otras localidades riojanas como Cuzcurrita, Tirgo, Enciso y Préjano 61.

Por fin, no nos podemos olvidar asimismo de los ingresos obtenidos mediante el ejercicio de labores profesionales como contadores al servicio de los monarcas o escribanos públicos ${ }^{62}$, así como otros trabajos de asesoramiento de los gobiernos municipales, sobre todo en relación con temas contables y financieros. En este sentido, por ejemplo, hay constancia de la intervención de mercaderes de Logroño y de Santo Domingo de la Calzada en las comisiones enviadas por los municipios a la Corte real para las negociaciones de los encabezamientos de alcabalas. Así se puede comprobar en el caso de los mercaderes de Santo Domingo de la Calzada, Sebastián de Ocio, Juan y Bartolomé Sánchez de Vergara, que negociaron a instancias del concejo de su ciudad el encabezamiento de las alcabalas de Santo Domingo en 1509; y también en el caso del mercader logroñés, Pedro de Yanguas, de quien hay constancia que fue facultado por el concejo de su ciudad en 1510 para negociar en la Corte el encabezamiento de las alcabalas de Logroño y su tierra ${ }^{63}$.

59 Ibídem., págs. 41-42.

${ }^{60}$ A.H.N.: NoblezA, Osuna, leg. 296, nº 1 y A.M.H.: L.A. 1467, sesión del 2 de abril.

${ }^{61}$ A.R.Ch.V.: P.C. Escribanía de Zarandona y Wals (O). C. 1206/3, leg. 261 y SÁinZ RipA, Eliseo: Santa María de La Redonda..., o.c., págs. 62-65.

${ }^{62} \mathrm{El}$ vecino de Logroño, Juan de Enciso, trabajó al servicio de la contaduría real en la primera mitad del siglo XVI (Álvarez Clavijo, María Teresa, Logroño en el siglo XVI: Arquitectura y urbanismo, Logroño, 2003, vol. I, pág. 172 y KellenbenZ, Hermann: Los Fugger en España y Portugal hasta 1560, Valladolid, 2000). También en la primera mitad del siglo XVI los mercaderes Sebastián de Ocio y Juan de Ocio ejercieron como escribanos públicos de número de la ciudad de Santo Domingo de la Calzada (Goicolea Julián, Fco. Javier: «La sociedad urbana riojana a fines del Medievo: Algunas consideraciones sobre la cultura del poder de varias familias representativas de la élite» en Poder, pensamiento y cultura en el Antiguo Régimen, San Sebastián, 2002, págs. 33-46).

63 A.M.S.D.C.: L.A. 1509, sesión del 1 de febrero y A.G.S.: E.M.R., leg. 690. 


\section{El PATRIMONIO ACUMULADO Y SU TRANSMISIÓN.}

Los lucrativos negocios desempeñados por los mercaderes de las ciudades y villas riojanas, les permitieron ir acumulando unos patrimonios cada vez mayores de bienes muebles y raíces que, si bien no eran comparables a las posesiones y fortunas de los mercaderes más ricos del Reino ${ }^{64}$, sí otorgaban a los mercaderes riojanos la consideración de «ricos» entre sus convecinos. Contamos con algunos datos sobre sus fortunas y haciendas, que eran valoradas por los mismos protagonistas en la ciudad de Santo Domingo de la Calzada en las primeras décadas del siglo XVI. Se trataba de estimaciones que iban desde los 3.000 ducados (1.125.000 maravedís) en que valoraba su hacienda el mercader Cristóbal de Ocio, pasando por los 1.000 ducados (375.000 maravedís) en que lo hacía su hermano Sebastián de Ocio, hasta los 200.000 maravedís que señalaba para su hacienda el mercader Diego Sánchez; quien, como los demás, se consideraba a sí mismo como una persona rica ${ }^{65}$. Como podemos comprobar nos encontramos ante estimaciones muy variadas, que ponen de manifiesto las diferencias de riqueza entre unos mercaderes y otros; lo cual se hace todavía más patente si añadimos algunos otros datos comparativos, referidos al volumen de negocio y a las dotaciones matrimoniales realizadas por mercaderes logroñeses en torno a las mismas fechas.

Por lo que respecta a la primera de las cuestiones, me referiré a los ingresos obtenidos de la venta de paños por el mercader Antonio de Yanguas en 1535, así como a las importantes compras de lana efectuadas por el mercader Diego de Yanguas en 1532 y 1535. En relación con Antonio de Yanguas, se puede comprobar que durante varios meses de 1535 , participó en veinticinco obligaciones de venta de paños, que fueron valoradas entre 1.632 y 29.578 maravedís, obteniendo un total de 128.832,5 maravedís. Mientras, en el caso de Diego de Yanguas, se puede constatar una primera compra de lana en 1532, que fue comprometida el 10 de septiembre, desembolsando el citado mercader 500.000 maravedís a un vecino de la ciudad de Soria; efectuándose la segunda venta en 1535, en este caso con el apoyo de su cuñado Hernando de Soria, quedando fijada la cuantía de la misma en 409.200 maravedís que fueron pagados a un vecino de Yanguas $^{66}$.

Y no menos significativas son las informaciones referidas al valor de algunas de sus propiedades, como la casa principal de Alonso de San Pedro, valorada en 2.500 ducados y un «cerrado» también de su propiedad valorado en otros $1.500^{67}$, así como las referencias a las dotaciones matrimoniales que efec-

${ }^{64}$ Casado Alonso, Hilario: El Triunfo de Mercurio..., o.c., págs. 135-162.

65 Goicolea Julián, Fco. Javier: «Sociedad y relaciones de poder..., o.c., págs. 277-279. $1535)$.

66 A.H.P.L.R.: P.N. Escribanía de Cristóbal Rodríguez. C. 472 (10-IX-1532) y 473 (28-VIII-

${ }^{67}$ Ibídem. C. 472 (26-VI-1532). 
tuaron en la primera mitad del siglo XV. En efecto, en 1532, el mercader Bernardino de San Pedro, hijo del también mercader Alonso de San Pedro y de Catalina de Soria, dejaba constancia de que sus padres habían dotado su matrimonio con Isabel de Porres con 6.000 ducados $^{68}$, y algunos años después, en 1535, podemos documentar que el matrimonio de Isabel de Bazán con Juan de Mendizábal fue dotado por sus padres, el mercader Hernando de Bazán y Juana de Arriaga, con una cantidad de 1.200 ducados de oro $^{69}$. Se trataba, en definitiva, de unas diferencias de riqueza que ya quedaban atestiguadas también entre los mercaderes logroñeses a finales del siglo XV, si nos atenemos a la cuantía individual de su contribución al préstamo realizado a la Corona en 1493, una cuantía que osciló entre los 13.000 maravedís aportados por los mercaderes más ricos, a los 1.000 maravedís aportados por los mercaderes de economías más modestas. En definitiva, a partir de este documento se puede deducir que el grado de riqueza de Juan Sánchez de Enciso el viejo y de su hijo Pedro de Enciso, de Cristóbal Moreno, de Fernando de Castro, de Sancho López de la Redonda, de Diego de Sesma o de Rodrigo de Yanguas «el viejo», era muy superior al de mercaderes de economías bastante más modestas como Juan de la Torre, Sancho Martínez de los Arcos, Alonso el Roxo el mozo o el mercero Enrique ${ }^{70}$.

Lógicamente fue a los mercaderes más poderosos, con más medios y mejor relacionados, a quienes el comercio y otros negocios igualmente rentables aportaron importantes ganancias que invirtieron en la compra de bienes inmuebles, tanto en las ciudades y villas como en sus entornos rurales. Así se pone de relieve, por ejemplo, en el testamento del mercader logroñés Hernando de Soria y en algún otro documento procedente de la ya citada escribanía de Cristóbal Rodríguez. En efecto, en el testamento que Hernando de Soria y su esposa redactaban en 1532, señalaban que junto a la casa principal que poseían en la Rúa Mayor, disponían igualmente de "casas y ençenses y rentas de casas y huerta y tinte del barrio que tenemos donde diçen la calle nueva del batetan», unas propiedades que, sin la huerta y el tinte, rentaban en torno a 20.000 maravedís, lo que nos permite comprobar que eran unos destacados propietarios de bienes inmuebles urbanos, que explotaban en parte mediante el régimen de arrendamiento, a semejanza de otros miembros de la élite ciudadana ${ }^{71}$.

El «negocio inmobiliario» se convertía de esta manera en una fuente más de ingreso de los mercaderes, tal y como se pone asimismo de manifiesto en el caso de Antonio de Yanguas, quien, en las primeras décadas del siglo XVI poseía solares de casas y casas en la Rúa Vieja, en la Rúa Mayor, en Barrio Mercado, en la Costanilla, e incluso fuera de la muralla de la ciudad de Logroño, donde además poseía un mesón «donde dizen la mancebia, con todo el establo

\footnotetext{
68 Ibídem.

69 A.H.P.L.R.: P.N. Escribanía de Francisco López de Salvatierra. C. 476 (12-II-1535).

70 Ver Tabla 1.

${ }^{71}$ Goicolea Julián, Fco. Javier: «La élite ciudadana de Logroño..., o.c., págs. 115-141.
} 
y pajar ${ }^{72}$. Hay constancia, en este sentido, de que Antonio de Yanguas obtenía diferentes rentas del alquiler de algunas de estas casas y solares, de la misma manera que también lo hacían otros mercaderes como Diego Díaz Navarro. Por lo que se refiere a Antonio de Yanguas, costa que el 21 de agosto de 1533 arrendó «a ençense perpetuo» un solar de casas situado en la calle Barrio Mercado a Pedro Aguado, a cambio de una renta de 500 maravedís anuales; mientras el mercader Diego Díaz Navarro arrendó ese mismo año de 1533 una casa situada en la Rúa Mayor a Alonso González de Albelda, quien se obligó a pagar al mercader 3.000 maravedís y 4 capones o 4 reales en cada uno de los cinco años de la duración del contrato de arrendamiento ${ }^{73}$.

El plantel de criados y servidores que trabajaban en las viviendas de los mercaderes, especialmente en sus casas principales, dejan constancia asimismo de la riqueza de sus amos, tal y como se puede comprobar a fines del siglo XV en el caso del mercader de Nájera, Alonso González de Belorado, quien «tenia sus caballos y escuderos en su casa y muchos criados» ${ }^{74}$. Y de la misma manera, los muebles, ajuar doméstico, objetos de oro y plata, etc. estaban en consonancia con el poderío económico de estas familias ciudadanas, constituyendo la abundancia y la calidad de estos objetos uno de los principales exponentes del lujo de la casa. María Teresa Álvarez Clavijo ha recopilado la información proporcionada por algunos inventarios de miembros de la élite logroñesa, que aunque algo posteriores a la cronología planteada en este estudio, son claramente indicadores de los refinados gustos de estos personajes, que poseían en sus casas imágenes, pinturas, retablos, objetos lujosos de madera, libros, objetos de oro y plata, joyas, cofres de diferentes clases, telas de seda y damasco, alfombras, tapices, etc.; objetos que en no pocas ocasiones tenían una procedencia extranjera. De Flandes, por ejemplo, donde los mercaderes logroñeses tenían intereses comerciales y financieros, tal y como hemos señalado en páginas anteriores, y se puede comprobar también en los inventarios de los bienes contenidos en la casa de Jerónimo Jiménez de Enciso e Isabel de Yanguas. Concretamente, en 1567, año en que Francisco de Soria Villoslada, primo de Jerónimo Jiménez, hacía inventario de todos los objetos que este último había comprado en Flandes, y señalaba expresamente que en su casa había un escaparate contador, procedente de este lugar; lo cual, nos podría estar informando sobre la conexión de estas familias elitistas con Europa y sus gustos ${ }^{75}$.

Las inversiones de mercaderes y hombres de negocio en inmuebles urbanos, fueron acompañadas también de adquisiciones de bienes rústicos. Así consta en el testamento ya citado del mercader Hernando de Soria y de su mujer Catalina Hernández de Navarrete, donde comprobamos igualmente que poseían

\footnotetext{
72 Álvarez Clavijo, María Teresa: Logroño en el siglo XVI..., o.c., vol. I, pág. 213.

73 A.H.P.L.R.: P.N. Escribanía de Cristóbal Rodríguez. C. 472 (21-VIII-1533 y 21-VI-1533).

74 A.R.Ch.V.: P.C. Escribanía de A. Rodríguez (F). C. 1020-1.

75 Álvarez Clavijo, María Teresa: Logroño en el siglo XVI..., o.c., vol. I, pág. 133.
} 
tierras en el entorno de la ciudad de Logroño, especialmente viñas y olivares ${ }^{76}$, que continuaban incrementando mediante la compra de nuevas haciendas, como la que habían adquirido en Lardero a Martín de Vergara, y que les situaba dentro del selecto grupo de los cosecheros vitivinícolas logroñeses más ricos, cuya privilegiada posición les permitía presionar a los productores menos pudientes, tal y como reflejan algunas quejas presentadas por vecinos de Logroño a fines del siglo $\mathrm{XV}^{77}$. Por lo demás, Hernando de Soria y su esposa eran igualmente propietarios de una papelería y de, por los menos, dos molinos en el término de Logroño, concretamente en la ribera del Ebro; molinos que fueron arrendados al molinero Martín de Segura el 21 de agosto de 1533. Efectivamente, por el contrato de arrendamiento escriturado, que tendría una duración de cuatro años, Martín de Segura se comprometía a pagar a Hernando de Soria 90 fanegas de trigo y dos capones todos los años ${ }^{78}$.

También eran propietarios de tierras y molinos algunos vecinos poderosos de Haro, como Diego López de Herrera, Antonio de Ribamartín, Diego Fernández de Ladrera y el licenciado Zobaco ${ }^{79}$; o de Calahorra, como los miembros de la familia Yanguas, Pedro Martínez de Yanguas, Francisco de Yanguas, Antonio de Yanguas y el doctor Juan Martínez de Yanguas, quienes obtenían asimismo rentas de la explotación de sus propiedades calagurritanas en la primera mitad del siglo XVI ${ }^{80}$. Y entre los ricos hacendados se encontraban también los miembros de la familia Ocio de Santo Domingo de la Calzada, en cuyos bienes inventariados en algunos documentos conservados, se enumeraban diversas tierras adquiridas en el propio término de la ciudad calceatense, así como en otras localidades. De esta manera se puede comprobar en el inventario recogido en el testamento que Juan Bautista de Ocio redactara hacia mediados del siglo XVI. En efecto, este documento nos proporciona algunos datos significativos sobre la posición socio-económica alcanzada por este representante de la familia Ocio, nieto de Diego López de Ocio e hijo de Antonio de Ocio. Entre sus bienes se encontraban diversas heredades de cereal, viñedos y linares situados en los pagos rurales de la ciudad de Santo Domingo, además de en las localidades de Castañares de Rioja, Villaporquera, Negueruela, Rodezno, Ollauri, Santurdejo y Villalobar, lugar este último en el que se inventariaba asimismo el molino que construyera su abuelo, Diego López de Ocio, en la segunda mitad del siglo $\mathrm{XV}^{81}$.

Los mercaderes riojanos, por lo demás, buscaron igualmente mejorar los patrimonios familiares mediante el acuerdo de matrimonios ventajosos, lo que

${ }^{76}$ En un Protocolo de la primera mitad del siglo XVI del escribano de Calahorra, Diego Ibáñez, consta que Pedro González Navarro y su mujer, Francisca Rejón, vendieron a Hernando de Soria, vecino de Logroño, una viña y pieza con treinta pies de olivos en el término de Logroño, por 18.000 maravedís (A.H.P.L.R.: Escribanía de Diego Ibáñez. C. 358).

77 A.G.S.: R.G.S., fol. 39 (14-IV-1496).

78 Goicolea Julián, Fco. Javier: «La élite ciudadana de Logroño..., o.c., págs. 115-141.

79 Goicolea Julián, Fco. Javier: Haro: Una villa riojana..., o.c., págs. 73 y 79.

80 A.H.P.L.R.: Escribanía de Diego Ibáñez. C. 358 (3-XI-1542 y 6-VI-1542).

81 A.H.P.A.: Archivo Familiar Ocio-Salazar, 21699. 
incrementó la endogamia entre las diferentes familias de mercaderes y hombres de negocio. Así se constata especialmente bien en la ciudad de Logroño, donde entre finales del siglo XV y primeras décadas del XVI hemos podido documentar la concertación de diferentes matrimonios entre las familias de la élite ciudadana de esa ciudad. Entre estos enlaces podemos destacar los que tuvieron como protagonistas a Pedro de Soria y Gracia de Yanguas; Hernando de Soria y Elvira Hernández de Navarrete; Diego de Yanguas y Graciosa Hernández de Navarrete; Alonso de San Pedro y Catalina de Soria; Pedro Moreno e Isabel de Castro; Miguel Moreno de León y María de Enciso; Juan Hernández de Navarrete y María Moreno; o a Juan de Enciso y Catalina de Yanguas. Ahora bien, la política matrimonial no se circunscribió únicamente a los enlaces entre familias de hombres de negocio, sino que se amplió también a la búsqueda de uniones con miembros de la nobleza señorial, tal y como se pone de manifiesto en el enlace ya citado que tuvo como protagonistas a Bernardino de San Pedro, hijo del mercader Alonso de San Pedro y de Catalina de Soria, e Isabel de Porres, hija del señor de Agoncillo, Francisco de Porres ${ }^{82}$.

Por supuesto, tampoco estaba ausente en este último caso el interés por dotar a la familia del componente de prestigio que suponía establecer vínculos con un linaje de acreditada condición nobiliaria; un objetivo que también estuvo presente en la motivación que dio origen al enlace establecido entre los Moreno y la familia hidalga de los León en las primeras décadas del siglo XVI. No podemos olvidar, en este sentido, que el acceso a la condición noble, como hidalgos, fue perseguida a fines de la Edad Media por algunos linajes de mercaderes de la ciudad de Logroño, entre los que se encontraban los Barrón o los Moreno ${ }^{83}$. Y en ambos casos tropezaron con serias dificultades, motivadas, entre otras razones, por la oposición de los miembros de la nobleza notoria a integrar en su seno a advenedizos «de oscura filiación» a quienes se acusaba de ser descendientes de judíos y conversos ${ }^{84}$. La participación en los «llamamientos» militares reales y el consiguiente mantenimiento de armas, caballos y escuderos fueron algunas de las medidas acordes con el ideal de vida caballeresco, puestas en práctica desde la segunda mitad del siglo XV por Juan Martínez Barrón, Juan Martínez Moreno, Cristóbal Moreno y otros miembros del estado ciudadano para ser considerados hidalgos, aunque únicamente sus descendientes del siglo XVI llegarán a alcanzar un reconocimiento

82 Ver documento IV del Apéndice.

83 Burgos Esteban, Francisco M.: «Las bases sociales del poder de la élite del estamento hidalgo. El linaje hidalgo de los Barrón (Logroño. Siglos XVI y XVII)» en Brocar (Logroño) 15 (1989) págs. 91-117 y GOICOLEA JULIÁN, Fco. Javier: «Sociedad y poder concejil..., o.c., págs. 87-112.

84 Sobre la procedencia judeo-conversa de los Moreno, ofrece algunos datos LORENZO CADARSO, Pedro Luis: «Oligarquización y luchas políticas en el ayuntamiento: 1512-1612» en Historia de la ciudad de Logroño, vol. III, Logroño, 1994, pág. 261. También tuvieron orígenes judíos otras importantes familias de mercaderes del Reino, como los poderosos Bernuy, originarios de Ávila, o los Sánchez de Bilbao de la ciudad de Vitoria (CASAdo Alonso, Hilario: El Triunfo de Mercurio..., o.c., págs. 138-141 y GARCÍA FERNÁNDEZ, Ernesto: Gobernar la ciudad..., o.c., págs. 326-334). 
que ya poseían mercaderes de otras ciudades riojanas, como los Ocio de Santo Domingo de la Calzada, desde el siglo $\mathrm{XV}^{85}$.

Los testamentos que escrituraron los mercaderes riojanos de esta época constituyen, en este sentido, no sólo unos fieles exponentes de la espiritualidad de quienes ordenaron escriturarlos, sino también son un reflejo suficientemente indicativo de la asimilación por parte de estos personajes de unos modos de vida acordes con el ideal caballeresco ${ }^{86}$. Este ideal, que a finales de la Edad Media tenía en la riqueza una de sus bases fundamentales, quedaba en consecuencia igualmente plasmado con la llegada de la muerte, a través de las costosas mandas pías, limosnas a los pobres, misas, aniversarios y capellanías que los mercaderes riojanos legaban en sus testamentos, pero sobre todo a través de la construcción de costosas capillas funerarias en las iglesias y conventos de las ciudades y villas, con las que trataban de proyectar su éxito terrenal y fortalecer y perpetuar al mismo tiempo el sentimiento de pertenencia a una familia.

\section{Tabla 6. Algunas disposiciones CONTENidas EN El TESTAMENTO DE PEDRO MORENO DE LEÓN (1536)}

- Ordena ser enterrado en la iglesia de Santa María de La Redonda, en la sepultura de la capilla familiar de San Juan Bautista donde están enterrados sus padres.

- Ordena que se celebre 1 misa diaria durante un año a partir del día de su entierro.

- Ordena que se celebren 9 misas cantadas de réquiem durante los nueve días posteriores a su entierro.

- Ordena que el día de su entierro se de comer a todos los pobres que se encontraran en la ciudad, además de proporcionar vestido y calzado a doce pobres.

- Ordena fundar 1 capellanía consistente en la celebración de cuatro misas semanales de forma perpetua, las cuales debían oficiarse los lunes, miércoles, viernes y sábados.

- Ordena pagar 2 ducados a los frailes de Valcuerna para que celebren una misa en su novena, y lo mismo establece en relación con los frailes del convento de San Francisco.

- Ordena entregar 2.000 maravedís al hospital de la ciudad.

- Ordena entregar 1.000 maravedís a la cofradía de la Misericordia.

- Ordena donar 7.000 maravedís para «casar huérfanas».

- Ordena distribuir 10.000 maravedís entre pobres «envergonçantes».

- Ordena celebrar 4 treintanarios en la iglesia de La Redonda.

- Ordena celebrar 2 aniversarios perpetuos en cada año.

- Ordena celebrar 1.000 misas durante el año en que acaeciera su muerte.

FuENTE: A.H.P.L.R.: P.N. Escribanía de Cristóbal Rodríguez. C. 473 (23-IX-1536).

${ }^{85}$ Goicolea Julián, Fco. Javier: «La sociedad urbana..., o.c., págs. 33-46.

${ }^{86}$ Un comportamiento que también se observa en otros linajes de comerciantes castellanos (CASAdo Alonso, Hilario: El Triunfo de Mercurio..., o.c., págs. 147-153) y europeos en general (LE Goff, Jacques: Mercaderes y banqueros de la Edad Media, Madrid, 2004, págs. 52-56). 
En relación con la ciudad de Logroño, sabemos que la familia Soria tenía predilección por el convento de San Francisco, lugar en cuya capilla de San Juan habían sido enterrados en el siglo XV Hernando Rodríguez de Soria y su esposa Clara Díaz, y donde asimismo habían levantado una capilla «de la Invocación de la Cruz» para su enterramiento, Hernando de Soria y Elvira Hernández de Navarrete, según su testamento escriturado en $1532^{87}$. Los Yanguas, por su parte, tenían predilección por la iglesia de Santa María de Palacio, templo del que eran parroquianos a fines de la Edad Media e inicios de la Moderna. En el siglo XV, por ejemplo, consta que en esta iglesia habían elegido sepultura Rodrigo de Yanguas y su esposa Juana Díaz, en una capilla que ellos mismos habían fundado, y el 20 de octubre de 1519 sabemos que otorgó su testamento, Pedro de Yanguas, fundando una capellanía en la iglesia de Santa María de Palacio, en su capilla de San Martín ${ }^{88}$. Otros hombres de negocio riojanos, por el contrario, eligieron como lugar de sepultura la iglesia de Santa María de La Redonda. Tales fueron los casos de algunos miembros de las familias Enciso, San Pedro o Moreno. Concretamente en relación con esta última familia, a través del testamento escriturado por Pedro Moreno de León en 1536, sabemos que los Morenos poseían en La Redonda una capilla dedicada a San Juan Bautista, donde debía ser sepultado Pedro Moreno de León «en la sepultura donde estan enterrados e sepultados Pero Moreno de Leon e Isabel de Castro mys sennores padres» ${ }^{89}$. Y noticias similares poseemos para la ciudad de Santo Domingo de la Calzada, donde sabemos que varios integrantes de la familia Ocio, concretamente Cristóbal de Ocio, Pedro de Ocio y Lope de Ocio, edificaron capillas en la catedral calceatense en la primera mitad del siglo XVI. En efecto, en 1538, y tras la preceptiva licencia del cabildo, Cristóbal de Ocio tomó posesión de la capilla que él mismo había edificado en la catedral y en la que iba a colocar su escudo de armas, y el 6 de marzo de 1543 consta que el cabildo de Santo Domingo de la Calzada concedió asimismo licencia a Lope de Ocio para construir una capilla en la iglesia catedral, junto a la capilla de Pedro de Ocio ${ }^{90}$. Algunos años después, hacia 1547, tenemos constancia de que un hijo del mercader Cristóbal de Ocio, también llamado Cristóbal, entró como novicio en el convento franciscano de la ciudad, lo que pone de manifiesto la atracción que los mendicantes ejercieron también entre las ricas familias de mercaderes de la ciudad calceatense ${ }^{91}$.

Se trataba, como hemos puesto de manifiesto en otro lugar ${ }^{92}$, de una espiritualidad que no difería de aquella propia de otros miembros de las élites urbanas de la Corona de Castilla en el tránsito de la Edad Media a la Moderna, y

\footnotetext{
87 Goicolea Julián, Fco. Javier: «La élite ciudadana de Logroño..., o.c., págs. 115-141.

88 Ibídem., pág. 129.

89 A.H.P.L.R.: P.N. Escribanía de Cristóbal Rodríguez. C. 473.

90 A.H.P.A.: Archivo Familiar Ocio-Salazar, 22539.

91 A.R.Ch.V.: P.C. Escribanía de Zarandona y Balboa (O). C. 890-9, leg. 1.

92 Goicolea Julián, Fco. Javier: «La élite ciudadana de Logroño..., o.c., pág. 130.
} 
que se plasmaba asimismo en el comportamiento de los mercaderes y hombres de negocio riojanos como mecenas de instituciones hospitalarias y conventuales. Poseemos algunos datos para la ciudad de Logroño. En efecto, en el siglo XV hay constancia de que Hernando Rodríguez de Soria y su esposa Clara Díaz habían edificado a su costa un hospital dedicado a Santiago en la calle de Santa María de Palacio, mientras su nieto el mercader Hernando de Soria había colaborado a fines del siglo XV e inicios del XVI en la edificación del nuevo hospital logroñés situado extramuros «...donde agora se acojen los pobres asi en lo bajo commo en lo alto los clerigos pobres e caseros» ${ }^{93}$. Y, junto a los Soria, los Enciso también figuraron entre los principales mecenas de la ciudad, siendo el contador del rey, Juan de Enciso, quien sufragó en las primeras décadas del siglo XVI la construcción del convento de la Madre de Dios, localizado junto a su casa ${ }^{94}$.

Por lo demás, la asimilación de los modos de vida caballeresco-nobiliarios por parte de los hombres de negocio, se ponía igualmente de manifiesto en la utilización cada vez más frecuente de fórmulas hereditarias que aseguraran la pervivencia de los bienes acumulados, o al menos de la parte principal, en el seno del linaje, mediante la constitución de «mejoras» de bienes en favor de alguno de los hijos, generalmente el primogénito. De esta manera se puede comprobar desde finales del siglo XV en Santo Domingo de la Calzada y en Nájera. En la primera de estas ciudades tenemos constancia de la fundación de un vínculo por parte de Diego López de Ocio en favor de su hijo, Antonio de Ocio, vínculo asociado a la mejora de unos bienes entre los que se contenían la casa principal, además de diversas heredades de cereal, viñedos, linares, y un molino edificado por Diego López de Ocio hacia 1474. En cuanto a la ciudad de Nájera, a través del testamento escriturado por Juan de Salinas en 1479, sabemos que este ciudadano reservaba de «mejora» la tercera parte de todos su bienes «asy muebles commo raices... en lo mejor parado de toda mi fazienda», a su hijo primogénito, Diego de Salinas; mientras a otro de sus hijos varones, Juan de Salinas, le reservaba la quinta parte de los bienes. Y las informaciones aumentan en la primera mitad del siglo XVI en relación con algunas familias de mercaderes y hombres de negocio de la ciudad de Logroño.

El mercader Alonso de San Pedro, por ejemplo, había reservado a su hijo, Bernardino de San Pedro, la tercera parte de sus bienes, entre los que se contenían la casa principal de la Rúa de las Tiendas, además de varias heredades tasadas en más de 1.000 ducados. La información procede del 1532, año en que redactaron igualmente su testamento el mercader Hernando de Soria y Elvira Hernández de Navarrete, quienes legaban a su hijo, Francisco de Soria, la casa paterna de la Rúa Mayor y todas las propiedades de «la calle nueva del batetan», dejando patente su voluntad de que todos los bienes «esten juntos

\footnotetext{
93 Ibídem., pág. 130

94 Álvarez Clavijo, María Teresa: Logroño en el siglo XVI..., o.c., vol. I, págs. 172-178.
} 
por via de mayorazgo o terçio e quinto de nuestros bienes commo mejor de derecho aya lugar»95. Algunos años después, en 1536, testaba Pedro Moreno de León, quien utilizaba también la vía de la «mejoria por via de mayoradgo» para transmitir a su hijo natural, Cristóbal Moreno de León, el juro de 102.000 maravedís que poseía en las alcabalas de la ciudad de Logroño y su merindad ${ }^{96}$.

En ambos casos, tanto Hernando de Soria como Pedro Moreno de Léon, especificaban cómo se debía proceder en la transmisión de los bienes para que se garantizara su pervivencia y su vínculo al linaje. De esta manera, Hernando de Soria estipulaba que sería el hijo varón primogénito de su hijo Francisco quien heredaría los bienes vinculados, y en caso de ausencia de varón, la hija mayor, aunque dejaba claramente asentada su predilección por los herederos varones, y entre ellos la preferencia de los legos sobre los clérigos ${ }^{97}$. Pedro Moreno de León, por su parte, establecía que el juro transmitido a su hijo, Cristóbal Moreno de León, debería heredarse de «hijo mayor a mayor legitimos e naturales», y en el caso de que Cristóbal no contara con descendencia masculina, el juro pasaría a su otro hijo natural, Miguel Moreno de León, de manera que sólo en el caso de que este último careciera de hijos varones o fuera clérigo, el vínculo podría ser transmitido a la hija mayor legítima de Cristóbal Moreno de León, poniéndose claramente de manifiesto también en este caso la preferencia por los herederos varones ${ }^{98}$.

Los dos hombres de negocio logroñeses dejaban asimismo establecida su voluntad de que los citados bienes que transmitían no pudieran ser enajenados en ningún caso. En efecto, Pedro Moreno de León declaraba en 1536 lo siguiente:

«que la dicha mejoria que ansi fago vinculada e subjeta a restituçion por via de mayorazgo no se puede vender ni enajenar ni trocar ni cambiar por ninguna via ni titulo ni cabsa sino que sienpre este e pase con el mismo vinculo a qualquier de las personas llamadas a la dicha subçesion»99.

\section{Y medidas similares señalaba Hernando de Soria en 1532:}

«que agora nin en ningund tiempo alguno perpetuamente no lo puedan dividir ni partir las dichas casas e barrio e huerta y tinte y ençenses y rentas de el, salvo que siempre este junto en poder de una persona aunque la dicha division se aga entre hermanos o en otra qualquier manera»100.

\footnotetext{
95 Goicolea Julián, Fco. Javier: «La élite ciudadana de Logroño..., o.c., págs. 133-141.

96 A.H.P.L.R.: P.N. Escribanía de Cristóbal Rodríguez. C. 473.

97 Goicolea Julián, Fco. Javier: «La élite ciudadana de Logroño..., o.c., págs. 133-141.

98 A.H.P.L.R.: P.N. Escribanía de Cristóbal Rodríguez. C. 473.

99 Ibídem.

100 Goicolea Julián, Fco. Javier: «La élite ciudadana de Logroño..., o.c., págs. 133-141.
} 
En definitiva, tanto Hernando de Soria como Pedro Moreno de León asumían esta fórmula hereditaria por razones económicas, pero también por prestigio familiar y pervivencia del linaje, de ahí que los titulares de los bienes mejorados tuvieran que llevar obligatoriamente los apellidos Soria y Moreno. En efecto, Hernando de Soria dejaba firmemente establecida su voluntad de que el titular de los bienes mejorados de su herencia «siempre se llame de Soria, y de otra manera que lo pierda y no lo pueda mas tener y pase a otro deçendiente pariente mas propincuo que se llame de Soria» ${ }^{101}$. Y lo mismo se puede comprobar en el testamento de Pedro Moreno de León, cuando señalaba de forma reiterada que el dicho vínculo que fundaba no podía ser heredado por ninguna institución eclesiástica, iglesia ni monasterio, debiendo de quedar de continuo «en Moreno para siempre jamas», de manera que en el caso de que el juro fuera heredado por un pariente "por linea femenina», éste siempre debería llevar el apellido Moreno además de tener reconocida su condición de «hombre hijodalgo", de lo que podemos deducir que los Morenos, o al menos Pedro Moreno de León, ya tenía reconocida tal condición en la primera mitad del siglo XVI ${ }^{102}$.

Hacia mediados de la centuria del quinientos, por fin, algunos de estos hombres de negocio más destacados de las principales ciudades riojanas, que habían conseguido consolidar y acrecentar su privilegiada posición socio-económica en el marco social urbano, completaron su «triunfo» con el control político concejil que les reportó la adquisición de regidurías municipales, puestas en venta por la Monarquía a partir del año 1543. En Santo Domingo de la Calzada los informes del corregidor establecían la posibilidad de obtener por cada oficio unos 300 ducados, siendo adquiridas las regidurías por algunos de los vecinos más acaudalados de la ciudad, entre los que se encontraban cuatro miembros del linaje Ocio: Francisco de Ocio, Diego de Ocio, Martín de Ocio y Lope de Ocio ${ }^{103}$. En Logroño, por su parte, cada candidato al regimiento tuvo que pagar 800 ducados por su oficio, un precio elevado que sólo estaba al alcance de algunos de los mercaderes más ricos de la ciudad, tales como Luis de Sesma, Hernando de Navarrete, Francisco de Gauna, Pedro de Enciso, Antonio de Yanguas, Diego de Yanguas o Hernando de Soria ${ }^{104}$. Y, por último, en Calahorra, entre los regidores perpetuos que ya ejercían su labor en 1544, se encontraban Juan Martínez de Yanguas, Antonio de Yanguas y Antón Tomás, tres poderosos representantes del estado ciudadano de la urbe calagurritana ${ }^{105}$. En definitiva, el dinero se convertía una vez más en elemento decisivo para canalizar ahora en favor de los mercaderes y hombres de negocio, la lucha por el poder que se dirimía en las principales ciudades riojanas desde los años finales de la Edad Media, dejando

${ }^{101}$ Ibídem.

102 A.H.P.L.R.: P.N. Escribanía de Cristóbal Rodríguez. C. 473.

103 Goicolea Julián, Fco. Javier: «Sociedad y relaciones de poder..., o.c., págs. 282-284.

104 Bañuelos Martínez, José María: El concejo de Logroño en los siglos de oro, Logroño, 1987, pág. 37.

${ }^{105}$ A.M.C.: L.A. 1544, sesión del 15 de enero. 
constancia de una autoridad que se había hecho patente asimismo en otras facetas de la vida social urbana riojana que hemos ido desgranando a lo largo de las páginas precedentes.

\section{A MOdo De CONClusión.}

Las actividades comerciales ocuparon a fines de la Edad Media e inicios de la Moderna, a un número significativo de vecinos de los núcleos urbanos riojanos, especialmente de ciudades principales como Logroño, Santo Domingo de la Calzada, Nájera o Calahorra. Estas actividades iban desde las más modestas, destinadas a abastecer de productos de primera necesidad a los vecinos de las ciudades y villas, hasta aquellas que superando los ámbitos locales se extendían al comercio comarcal e interregional, e incluso internacional, tal y como ha quedado plasmado en las páginas de este estudio. Fueron precisamente las empresas más costosas y ambiciosas que superaron las fronteras del Reino, las que produjeron mayores beneficios a los mercaderes riojanos, unos mercaderes que, como hemos podido documentar especialmente en el caso logroñés, comercializaban lana en los mercados regionales e internacionales, además de paños que distribuían en los ámbitos locales y regionales. No cabe duda de que fueron estas actividades comerciales las que estuvieron en el origen de las fortunas acumuladas por un buen número de mercaderes riojanos, aunque no fueron sus únicas fuentes de ingresos. Por el contrario, los mercaderes riojanos complementaron sus negocios comerciales con la propia producción de paños, documentada especialmente en Santo Domingo de la Calzada, y con otras actividades como el arrendamiento de rentas reales, concejiles y eclesiásticas, el ejercicio de profesiones en sus ciudades y villas, el préstamo o la inversión en deuda pública, los denominados «juros al quitar».

Asimismo, sus negocios cada vez más rentables permitieron a los mercaderes riojanos invertir un porcentaje de sus ganancias en la adquisición de bienes inmuebles urbanos, casas principalmente, y rústicos, tierras de cereal, vid, olivares, linares, etc., además de molinos, con los que conformaron unos patrimonios considerables que explotaron en parte mediante su arrendamiento a particulares. No cabe duda de que detrás de estas inversiones se hallaba un interés económico calculado por los hombres de negocio, pero también el deseo no menos importante a finales de la Edad Media de llevar un modo de vida acorde con la mentalidad caballeresca propia de la élite señorial nobiliaria, que tenía en la posesión de la tierra y en las rentas derivadas de su explotación una base fundamental de su riqueza y consideración social. De ahí la asunción por parte de los mercaderes riojanos de fórmulas hereditarias (vínculos y mejoras) que primaran a alguno de los herederos con la consiguiente supervivencia del patrimonio familiar dentro del linaje, así como el interés de algunas familias de hombres de negocio logroñeses por la búsqueda de vínculos familiares con 
miembros de la nobleza señorial, aunque fuera con linajes de segunda fila, como los Porres. Y de ahí también el interés de un número cada vez más importante de mercaderes y hombres de negocio procedentes del estado ciudadano por ennoblecerse y acceder a la condición hidalga, condición indispensable a fines de la Edad Media para seguir progresando socialmente. Hacia mediados del siglo XVI varias familias riojanas de hombres de negocio ya habían logrado este objetivo y se habían encaramado en lo más alto de la pirámide social de sus ciudades, confirmando un triunfo social que completaron con la compra de un buen número de las regidurías municipales puestas en venta durante el reinado de Carlos V. 


\title{
APÉNDICE DOCUMENTAL
}

\author{
I
}

1532, 30-VI. Logroño.

Hernando de Soria, Antonio de Yanguas, Diego de Yanguas y Bartolomé de Poza avalan a Rodrigo de Soria, residente en Brujas, en el desempeño de sus funciones de factor del mercader de Burgos, Gómez de Nájera.

A.H.P.L.R.: P.N. Escribanía de Cristóbal Rodríguez. C. 472.

Sepan quantos esta carta vieren como nos Hernando de Soria y Antonio de Yanguas y Bartolome de Poza y Diego de Yanguas, vesinos de la çibdad de Logronno juntamente de mancomun a voz de uno cada uno de nos por si e por el todo in solidum renunçiando commo espresamente renunçiamos la ley de duobus reys e la autentica presente hoc yta fide iusoribus y el benefiçio de la dibision y la ley que dize que sea hecha discusion en bienes del que reçibe la cosa antes que en los del fiador o obligado juntamente e todas otras leys que para lo yuso contenido nos puedan aprobechar en general y en espeçial commo si aqui fuesen insertas, otorgamos y conoçemos por esta presente carta y dezimos que por quanto vos Gomez de Najera veçino de la çibdad de Burgos a nuestra contenplaçion tomays e abeys tomado contrataçion con Rodrigo de Soria vesino que fue de la dicha çibdad de Logronno que al presente esta y reside en la villa de Brujas que es en el condado de Flandes, para que el dicho Rodrigo de Soria aya de entender y entienda en las cosas e contrataçiones del trato de mercaderia en que vos el dicho Gomez de Najera tratais, el qual a de cobrar y cambiar las letras de cambio que vos le enviaredes y enbiaros el retorno conforme a vuestras cartas segund uso y harte y trato de mercaderes y personas que tratan en el trato y harte que vos el dicho Gomez de Najera tratays y el dicho Rodrigo de Soria entiende y trata, al qual vos el dicho Gomez de Najera le dais e pagais y abeis de dar en encomienda sengund e como se da y paga a otras personas que entienden y tratan por via de fatoria, lo qual esta asentado y capitulado con el dicho Rodrigo de Soria y con nosotros en su nonbre. Por ende dezimos que aziendo en este caso commo azemos de cosa y deuda ajena propia nuestra y hecha por nos y en nuestro nonbre que nos obligamos con nuestras personas y bienes muebles y raizes, derechos, açiones avidos e por aver e de cada uno de nos yn solidum, que el dicho Rodrigo de Soria hara y entendera en el dicho açimiento que ansy por vos el dicho Gomez de Najera le fuere ynviado y encargado y encomendado con toda soliçitud y diligençia como buen fator es obligado a lo azer y os dara cuenta y razon y pago verdadero sin pleito ni revuelta alguna de todo aquello que por vuestras cartas o letras de cambio o qualquier de ello le inviaredes que cobre agora o canbie asy en las letras que de aca le inviaredes que cobre como de lo que por vuestras cartas le escribieredes os invie de retorno e hara en todo ello y cada cosa e parte de ello commo todo buen fator es obligado ha azer y os dara la dicha cuenta y pago cada y quando que vos el dicho Gomez de Najera se la pidierades y segund y commo se acostumbra ha azer y dar entre mercaderes y personas que tratan, y no lo dando segund e commo dicho es nosotros e cada uno de nos yn solidum seamos obligados y nos obligamos a vos la dar e vos la daremos dentro de tres dias que por vos seamos requeridos conforme a vuestro libro syn poner exençion ni escusa ni dilaçion alguna y que vos pagaremos todo el alcançe que nos hizieredes y alcan- 
çaredes dentro de sesenta dias despues de hecho el dicho alcançe commo dicho es, e sy caso fuere que algunos de los dineros que asi el dicho Rodrigo de Soria reçibiere en nonbre de vos el dicho Gomez de Najera quier sea por letras de cambio o cartas misibas o por otra qualquier escritura o syn ella o por otra qualquier via que lo reçiba por vos el dicho Gomez de Najera, los tomare para nosotros o qualquier de nos yn solidum e diere sus letras sobre nosotros o qualquier de nos para que ayamos de pagar e paguemos la suma y cantidad que asy tomare e por la çedula o çedulas o letras de cambio ynbiare a dezir que paguemos a vos el dicho Gomez de Najera o a quien vuestro poder oviere desde agora para entonzes y de entonzes para agora, açebtamos y abemos por açebtadas las tales çedulas, letras de cambio en caso que las tales çedulas o letras ablen con uno de nos en particular o con todos nosotros todos cuatro commo dicho es e in solidum las açetamos y abemos por açetadas para que juntamente e cada uno in solidum seamos obligados e nos obligamos a las pagar nos e qualquier de nos en las partes y lugares y a los plazos y tienpos y segund y commo y en la forma e manera que en las tales letras o çedulas de cambio o qualquier de ello fuere declarado e asi las podais protestar contra nos o qualquier de nos insolidum no las cunpliendo e pagando, e seamos obligados y nos obligamos a vos pagar y que pagaremos a vos el dicho Gomez de Najera o a quien vuestro poder ubiere la suma contenida en las tales letras o çedulas de cambio con todos los protestos, canbios y recanbios, costas e dannos, intereses y perdidas y menoscabos que a la cabsa se bos recreçieren, sobre lo qual seais creido por el dicho Gomez de Najera o a quien vuestro poder ubiere por vuestro juramento o de quien el dicho vuestro poder ubiere, e lo que asi juraredes e declararedes aquello seamos obligados a vos pagar sin pleito ni revuelta alguna sin enbargo de la ley que dize que el que queda de estar a juramento o declaraçion de otro sobre costas o dannos que antes de la declaraçion pueda reclamar de la confision, y no enbargante que sea nesçesario y se requiera segund derecho, uso y costunbre e harte de tratantes y mercaderes ser requeridos con las tales letras o çedulas de cambio, o en caso que en ellas o qualquier de ellas se diga, esprese o declare que seamos requeridos, o que diga o declare en las tales letras o çedulas de cambio que paguemos a çierto plazo en la dicha çedula declarado vista, queremos y se entienda sin aver visto las dichas çedulas de cambio ni aver sido requerido con ellas nos o qualquier de nos, sean açetadas y las açetamos desde agora para las pagar segund y como y de la forma y manera y so las penas y posturas en esta carta declaradas y cada una de ellas. Para lo qual todo que dicho es y cada una cosa y parte de ello tener y guardar y cunplir, pedimos e rogamos e damos poder cunplido a todas e qualesquier justiçias asi de la casa y corte y chanzelleria de sus magestades commo sometiendonos como nos sometemos a su jurediçion commo si dentro de las çinco leguas de ella viviesemos e morasemos, e a todas las otras justiçias de todas las çibdades, villas y lugares de estos reinos e sennorios e a la jurediçion del prior e consules de la çibdad de Burgos commo personas que tienen jurediçion o facultad de sus magestades para entre las personas mercaderes y tratantes commo si dentro de la dicha çibdad de Burgos viviesemos e morasemos e fuesemos de la dicha universidad, e cada uno de ellos ante quien esta carta paresçiere y de ella y de lo en ella contenido fuere pedido cunplimiento de derecho, que nos costringan, conpelan e apremien a nos o a qualquier de nos insolidum a tener y guardar e cunplir lo en esta carta contenido cada una cosa e parte de ello bien asi e tan cunplidamente commo si los dichos juezes e justiçias o qualquier de ellos asi lo oviesen juzgado y sentençiado por su juizio y sentençia definitiva dada a nuestro pedimiento y consentimiento e de cada uno de 
nos fuese pasada en cosa juzgada, tal que de ella ni de parte de ella no obiese ni pudiese aver apelaçion, suplicaçion, nulidad ni agravio ni otro remedio ni recurso alguno por via de injusta sentençia ni por otra causa, titulo ni razon alguna que sea que podamos tener de hecho ni de derecho en caso que se requiera espresar en esta escritura o espresamente renunçiarse, e renunçiamos nuestro fuero e jurediçion e domeçilio e de cada uno de nos in solidum e la ley sid convenerit de jurediçione en todo y por todo segund y commo en ella se contiene, y todas otra leys, fueros y derechos e hordenamientos viejos e nuebos escritos, canonicos e çebiles de que nos podamos aprobechar en repreender e contradezir esta carta, e renunçiamos la ley que dize que el derecho proybitibo ni el dolo futuro no se pueda renunçiar. Otrosy renunçiamos todas otras leys en general y en espeçial que sean en nuestro favor o de qualquier de nos in solidum para repreender o contradezir esta carta o su registro en general y en espeçial e la ley del derecho que dize que general renunçiaçion que home faga que non bala, en testimonio de lo qual otorgamos esta carta ante el escribano y testigos de yuso escritos y la firmamos de nuestros nonbres, que fue fecha y otorgada en Logronno a treinta dias del mes de junio anno del nasçimiento de nuestro salvador Jesuchristo de mill e quinientos e treinta e dos annos, a lo qual fueron presentes por testigos Rodrigo de Luçuriaga e Viçente de Poza e Miguel de Segura, vesinos de la dicha çibdad de Logronno.

\section{II}

1532, 17-VII. Logroño.

El mercader Diego Rodríguez da poder a su hermano, Cristóbal Rodríguez, para que pueda comprar paños y otras mercancías en Bilbao por una cuantía de 90.000 maravedís.

A.H.P.L.R.: P.N. Escribanía de Cristóbal Rodríguez. C. 472.

Sepan quantos esta carta de poder vieren commo yo Diego Rodriguez, mercader vesino que soy de la muy noble e muy leal çibdad de Logronno otorgo e conozco por esta presente carta que doy e otorgo todo mi poder que mejor e mas cumplidamente lo puedo e devo dar e otorgar e de derecho mas puede e debe valer a vos Christoval Rodrigues mi hermano, vesino de la dicha çibdad de Logronno que estais presente espeçialmente para que por mi y en mi nombre e commo yo mismo podais comprar e compreis en la villa de Vilbao de qualesquier personas y mercaderes que quisieredes e por bien tovieredes ansi vesinos de la dicha villa de Vilbao commo de otras partes e lugares qualesquier de qualesquier mercadurias ansi de pannos commo de otras cosas hasta en quantia de noventa mill maravedis y dende abaxo la cantidad que quisieredes e por bien tobieredes, e para que ansi tomadas las dichas marcaderias podais otorgar e otorgueis qualesquier escrituras que nesçesarias sean y os fueren pedidas ansi de obligaçiones como en otra qualquier manera, y obligar e obligueis mi persona e bienes muebles e rayzes avidos e por aver en las tales escripturas con poder a las justiçias e renunçiaçiones de leys que nesçesarias sean y os fueren pedidas, que yo dende agora me doy por obligado a ellas y las doy por otorgadas e renunçiadas e por buenas y bastantes y valederas commo si yo mismo las diese e otorgase e a las data e otorgamiento de ellas presente fuese e de mi nombre fuesen firmadas, e hazer e hagades todas aquellas cosas e diligençias e cada una de ellas que yo mismo haria e hazer 
podria presente seyendo, aunque sean tales e de tal solidez que en si segund derecho demanden e requieran aver otro mi mas espeçial poder e mandado e presençia personal, e quand cumplido e bastante poder commo yo he y tengo para todo lo que dicho es e para qualquier cosa e parte de ello otro tal e tan cumplido (Tachado) e bastante y ese mismo doy e otorgo a vos el dicho Christobal Rodrigues mi hermano con todas sus inçidençias e dependençias, emergençias, anexidades e conexidades, e con libre e franca e general administraçion, e si nesçesario es relebaçion vos reliebo de toda carga e costa de satisfaçion e frança e cabçion so aquella clausula del derecho que es dicha en latin iudiçio sisti iudicatum solvi con todas sus clausulas acostumbradas. E porque abre por bueno todo lo que sobre esto fazieredes y no ire ni verne contra ello, obligo mi persona e bienes muebles e rayzes avidos e por aver, en testimonio de lo qual otorgue esta carta de poder y lo en ella contenido ante vos el escribano publico e testigos de yuso escriptos, que fue fecha e otorgada en la dicha çibdad de Logronno a diez e siete dias del mes de jullio anno del nasçimiento de nuestro salvador Ihesu Christo de mill e quinientos e treinta e dos annos, a lo qual fueron presentes por testigos Juan de Navarrete e Garçia de Soto e Gaspar de Soria, vesinos de la dicha çibdad de Logronno, y el dicho otorgante lo firmo de su nombre. Diego Rodrigues.

1532, 21-IX. Logroño.

Hernando de Soria, Diego de Yanguas y Antonio de Yanguas, mercaderes de Logroño, se comprometen a hacer efectivo un pago de 2.000 coronas de oro en Brujas, a los vecinos de Burgos, Gracián y Hernando de Matanza.

A.H.P.L.R.: P.N. Escribanía de Cristóbal Rodríguez. C. 472.

Sepan quantos esta carta de obligaçion vieren commo nosotros Hernando de Soria, Diego de Yanguas, Antonio de Yanguas, mercaderes vezinos que somos de la muy noble y muy leal çibdad de Logronno, otorgamos e connosçemos por esta presente carta e dezimos que por quanto yo el dicho Diego de Yanguas doy letras de cambio de dos mill coronas de oro que Françisco Rodrigues mercader vesino de la dicha çibdad de Logronno tomo de cambio de vosotros Graçian y Hernando de Matança vesinos de Burgos en esta presente feria de Rioseco de este presente anno de mill e quinientos e treinta e dos annos, y las dichas letras que doy son de las dichas dos mill coronas de a seys sueldos de gruesos corona moneda de Flandes sobre Rodrigo de Soria estante en Brujas a pagarlas en feria de Brujas de pascua de navidad primera viniente de este presente anno a tiempo de pagos. Por ende que nos obligamos con nuestras personas e bienes muebles e rayzes avidos e por aver todos tres juntamente de mancomun a voz de uno e cada uno de nos por si e por el todo in solidum renunçiando la ley de duobus rex devendi y la autentica presente de fide iusoribus e todas las otras leys, fueros e derechos que son e hablan en razon de la mancomunidad, que el dicho Rodrigo de Soria pagara las dichas dos mill coronas de oro en la dicha feria de Brujas de navidad segund e commo en las dichas çedulas se contiene, a Juan de Matança estante en Brujas o a quien su poder obiere, y que si el dicho Rodrigo de Soria no pagare las dichas dos mill coronas segund dicho es a tiempo de pagos, que nosotros y qualquier de nos las pagaremos con los canbios y recanbios segund e como paresçiere poner por testi- 
monios mas todas las costas e dannos e menoscabos que sobre ello se siguieren e resçivieren por quanto el balor de las dichas dos mill coronas de oro reçibimos yo el dicho Diego de Yanguas de vos los dichos Garçia y Hernando de Matança en el cambio de Gregorio de Santa Maria veçino de Burgos. Y en razon de ello y para lo ansi mejor tener e guardar e cumplir e pagar renunçiamos e partimos de toda nuestra ayuda e fabor todas quantas leys son del fuero e del derecho canonicas e çibiles, comunales e muniçipales escriptas e por escribir ansi en general como en particular y por esta presente carta pedimos e damos todo nuestro poder cunplido a todas las justiçias qualesquier que sean de sus magestades de sus reinos e sennorios para que nos prendan e hagan executar en los dichos nuestros bienes y ansi nos lo fagan tener e guardar e cunplir e pagar aun mas los canbios e recanbios e costas bien ansi e tan cunplidamente commo si por los dichos juezes e justiçias o por qualquier de ellas ansy fuese juzgado e sentençiado por su juizio e sentençia definitiva e fuese por nos consentida e aprobada e pasada en cosa juzgada. En los quales dichos juezes e justiçias fazemos espresa prorrogaçion de juridiçion e nos sometemos a su juizio e sentençia renunçiando nuestro propio fuero e juridiçion e nos sometemos a su juizio e sentençia renunçiando a nuestro propio fuero e juridiçion (sic) e domiçilio e la ley de dolo malo e de la infinta del enganno e todo benefiçio de restituçion in integrum e todas ferias e mercados francos e por franquear de pan e vino coger de comprar e de vender y la ley de derecho en que dize que general renunçiaçion de leys que home faga que non vala salvo renunçiando esta ley. En testimonio de lo qual otorgamos esta carta de obligaçion y lo en ella contenido ante vos el escrivano publico e testigos de yuso escriptos, que fue fecha e otorgada en la çibdad de Logronno a veinte e un dias del mes de setiembre anno del nasçimiento de nuestro salvador Ihesu Christo de mill e quinientos e treinta e dos annos, a lo qual fueron presentes por testigos Pedro de Yanguas e Juan de Navarrete e Garçia de Soria, vesinos de la dicha çibdad de Logronno y los dichos otorgantes lo confirmaron de sus nonbres.

IV

\section{2, 26-VI. Logroño.}

Dote matrimonial aportada por el señor de Agoncillo, Francisco de Porres, para el matrimonio de su hija, Isabel de Porres, con Bernardino de San Pedro.

A.H.P.L.R.: P.N. Escribanía de Cristóbal Rodríguez. C. 471.

Sepan quantos esta carta de obligaçion, dote e casamiento vieren como yo Françisco de Porres, sennor de las villas de Agonçillo y Estrimiana, otorgo e conozco por esta presente carta, digo que por quanto contratadas palabras de matrimonio para que mediante la voluntad de Dios nuestro sennor, dona Isabel de Porres, mi hija, se aya de desposar y casar segund horden de la Santa madre iglesia de Roma con Bernardino de San Pedro, vezino de la çiudad de Logronno, e porque el dicho casamiento aya efeto, por ende que me obligo con mi persona e vienes muebles e rentas e rayzes avidos e por aver por dar e pagar, e que dare e pagare a vos el dicho Bernardino de San Pedro en el dicho dote e casamiento mill e quinientos ducados de oro y de peso que montan quinientos e sesenta e dos mill e quinientos maravedis pagados en esta manera: los mill ducados de oro quinze dias antes que os veleis e caseis con la dicha dona Isabel de Porres, mi hija, y los quinientos ducados restan- 
tes fin de pago dentro de dos annos despues que os velaredes e casaredes, so pena del doblo de los dichos mill e quinientos ducados que vos de y pague en pena y en postura y en nonbre de propio interes e convençional los dichos plazos pasados en adelante, en razon de lo qual renunçio e aparto e quito de toda mi ayuda e favor todas quantas leys son del fuero y del derecho con las del ordenamiento real canonicas y çiviles comunnales e muniçipales escriptas e por escribir ansy en general commo en espeçial e todas exençiones e preminençias e libertades ansy de caballero como de ydalgo como en otra qualquier manera de que en este caso yo me pueda aprovechar e me pueda conpeter e conpeta de derecho en qualquier manera, que todo lo renunçio e aparto e quito de mi e de toda ayuda e favor, e por esta presente carta pido e doy todo mi poder cumplido a todas las justiçias qualesquier que sean de sus magestades de sus reynos e sennorios e a los alcaldes de su casa y corte e chançellerias como si bibiese e morase dentro de las çinco leguas para que me prendan e hagan esecuçion en los dichos mis bienes e rentas, e ansi me lo hagan tener e guardar e cunplir e pagar con mas la pena y las costas bien ansi e tan cumplidamente como si los juezes e justiçias o por qualquier de ellas ansi fuese juzgado e sentençiado por su juizio e sentençia definitiva e fuese por mi consentida e aprobada e pasada en cosa juzgada, en los quales dichos juezes e justiçias hago espresa prorrogaçion de jurisdiçion y me someto a su juizio e sentençia renunçiando mi propio fuero e jurisdiçion e domiçilio e la ley del dolo malo e de la ynfinta del enganno e todo benefiçio de restituçion in integrund e todas ferias e mercados francos e por franquear de pan e vino coger y de comprar e de vender, e la ley del derecho en que dize que general renunçiaçion de leys que ome faga que non bala, salvo renunçiando esta ley. En testimonio de lo qual otorgue esta carta de obligaçion, dote e casamiento y todo lo en ella contenido ante vos el escribano publico y testigos de yuso contenidos, que fue hecha y otorgada en la dicha çiudad de Logronno a veynte e seys dias del mes de junio anno del nasçimiento de nuestro salvador Ihesu Christo de mill e quinientos e treinta e dos annos, a lo qual fueron presentes por testigos el dotor Diego Fernandez de Navarrete e Fernando de Soria e Antonio de Yanguas e Diego de Yanguas, vezinos de la dicha çiudad de Logronno. Y el dicho otorgante lo firmo de su nonbre. Françisco de Porres. E yo Christobal Rodrigues escrivano de sus magestades e su notario publico en la su corte y en todos los sus reynos e sennorios y escribano publico del numero de la dicha çiudad de Logronno que a todo lo que dicho es presente fuy en uno con los dichos testigos e de otorgamiento del dicho Françisco de Porres que en el registro de esta carta de obligaçion lo firmo de su nonbre e de pedimiento del dicho Bernaldino de San Pedro, lo fize escribir y escribi y por ende fize aqui este mio signo atal en testimonio de verdad. Christobal Rodriguez. 